\title{
Article \\ Effects of a Cc2d1a/Freud-1 Knockdown in the Hippocampus on Behavior, the Serotonin System, and BDNF
}

\author{
Elena M. Kondaurova ${ }^{*}{ }^{\dagger}$, Alexandra V. Plyusnina *, ${ }^{+}$, Tatiana V. Ilchibaeva (D, Dmitry V. Eremin, \\ Alexander Ya. Rodnyy, Yulia D. Grygoreva and Vladimir S. Naumenko
}

\section{check for}

updates

Citation: Kondaurova, E.M.; Plyusnina, A.V.; Ilchibaeva, T.V.; Eremin, D.V.; Rodnyy, A.Y.; Grygoreva, Y.D.; Naumenko, V.S. Effects of a Cc2d1a/Freud-1 Knockdown in the Hippocampus on Behavior, the Serotonin System, and BDNF. Int. J. Mol. Sci. 2021, 22, 13319. https:// doi.org/10.3390/ijms222413319

Academic Editors: Javier Díaz-Nido, S. Herranz-Martin and Ahad Rahim

Received: 12 November 2021 Accepted: 9 December 2021

Published: 11 December 2021

Publisher's Note: MDPI stays neutral with regard to jurisdictional claims in published maps and institutional affiliations.

Copyright: (c) 2021 by the authors. Licensee MDPI, Basel, Switzerland. This article is an open access article distributed under the terms and conditions of the Creative Commons Attribution (CC BY) license (https:// creativecommons.org/licenses/by/ $4.0 /)$.
The Federal Research Center Institute of Cytology and Genetics (ICG), Siberian Branch of Russian Academy of Sciences (SB RAS), 630090 Novosibirsk, Russia; ilchibaeva@bionet.nsc.ru (T.V.I.); eremin@bionet.nsc.ru (D.V.E.); arodnyi@bionet.nsc.ru (A.Y.R.); grigorevaulia@bionet.nsc.ru (Y.D.G.); naumenko2002@bionet.nsc.ru (V.S.N.)

* Correspondence: kond_em@bionet.nsc.ru (E.M.K.); sashaplusnina@gmail.com (A.V.P.)

+ Equal contribution.

Abstract: The serotonin 5- $\mathrm{HT}_{1 \mathrm{~A}}$ receptor is one of the most abundant and widely distributed brain serotonin (5-HT) receptors that play a major role in the modulation of emotions and behavior. The 5- $\mathrm{HT}_{1 \mathrm{~A}}$ receptor gene $(\mathrm{Htr} 1 a)$ is under the control of transcription factor Freud-1 (also known as Cc2d1a/Freud-1). Here, using adeno-associated virus (AAV) constructs in vivo, we investigated effects of a Cc2d1a/Freud-1 knockdown in the hippocampus of C57BL/6J mice on behavior, the brain 5-HT system, and brain-derived neurotrophic factor (BDNF). AAV particles carrying the pAAV_H1-2_shRNAFreud-1_Syn_EGFP plasmid encoding a short-hairpin RNA targeting mouse Cc2d1a/Freud-1 mRNA had an antidepressant effect in the forced swim test 5 weeks after virus injection. The knockdown impaired spatiotemporal memory as assessed in the Morris water maze. pAAV_H1-2_shRNA-Freud1_Syn_EGFP decreased Cc2d1a/Freud-1 mRNA and protein levels. Furthermore, the Cc2d1a/Freud-1 knockdown upregulated 5-HT and its metabolite 5-hydroxyindoleacetic acid but not their ratio. The Cc2d1a/Freud-1 knockdown failed to increase mRNA and protein levels of Htr1a but diminished a $5-\mathrm{HT}_{1 \mathrm{~A}}$ receptor functional response. Meanwhile, the Cc2d1a/Freud-1 knockdown reduced Creb mRNA expression and CREB phosphorylation and upregulated $c F o s$ mRNA. The knockdown enhanced the expression of a BDNF precursor (proBDNF protein), which is known to play a crucial part in neuroplasticity. Our data indicate that transcription factor $C c 2 d 1 a /$ Freud-1 is implicated in the pathogenesis of depressive disorders not only via the $5-\mathrm{HT}_{1 \mathrm{~A}}$ receptor and transcription factor CREB but also through an influence on BDNF.

Keywords: Cc2d1a/Freud-1 knockdown; AAV; 5-HT; 5-HT 1 A receptor; mouse; CREB; BDNF

\section{Introduction}

It is well known that brain serotonin (5-HT) plays an important role in the regulation of many physiological processes and is involved in the control of various types of normal and pathological behaviors, including depression [1-4]. Numerous studies show a key function of the serotonin $5-\mathrm{HT}_{1 \mathrm{~A}}$ receptor in the regulation of the functional state of the brain 5-HT system [4]. In this regard, this receptor has attracted the attention of many researchers. This receptor in midbrain raphe nuclei acts as a somatodendritic autoreceptor inhibiting neuronal activity and 5-HT secretion into the synaptic cleft. In addition, 5- $\mathrm{HT}_{1 \mathrm{~A}}$ receptors are localized postsynaptically. The postsynaptic and presynaptic $5-\mathrm{HT}_{1 \mathrm{~A}}$ receptors affect neuronal activity differently $[4,5]$. Substantial data indicate the involvement of the $5-\mathrm{HT}_{1 \mathrm{~A}}$ receptor in the pathogenesis of depression [6-11], depressive psychosis [12], and suicidal behavior [13-15] as well as in the mechanisms of antidepressant-drug action [11,16]. Alterations of the $5-\mathrm{HT}_{1 \mathrm{~A}}$ receptor level are commonly observed in depressed individuals. In particular, the postsynaptic $5-\mathrm{HT}_{1 \mathrm{~A}}$ receptor is downregulated in several cortical regions in depression [17-21] and anxiety [22-24], whereas the 5- $\mathrm{HT}_{1 \mathrm{~A}}$ autoreceptor is overexpressed in depression $[14,25,26]$. In this context, elevated $5-\mathrm{HT}_{1 \mathrm{~A}}$ autoreceptor expression tends to 
reduce the activity of 5-HT neurons, while underexpression of the postsynaptic 5- $\mathrm{HT}_{1 \mathrm{~A}}$ receptor may blunt a behavioral response to 5 -HT. These data indicate that the $5-\mathrm{HT}_{1 \mathrm{~A}}$ receptor is a major determinant of predisposition to mental disorders.

It is acknowledged that alterations in the $5-\mathrm{HT}_{1 \mathrm{~A}}$ gene expression can differentially affect the functional activity of the brain 5-HT system via various effects on pre- and postsynaptic $5-\mathrm{HT}_{1 \mathrm{~A}}$ receptors. In view of crucial implication of the $5-\mathrm{HT}_{1 \mathrm{~A}}$ receptor in the autoregulation of brain 5-HT system [4], factors underlying the 5- $\mathrm{HT}_{1 \mathrm{~A}}$ receptor gene expression adjustment could be among potential targets for 5-HT-dependent behavior regulation. Nevertheless, mechanisms for $5-\mathrm{HT}_{1 \mathrm{~A}}$ receptor functional state control are still far from being completely elucidated.

In 2000 , in the promoter of the gene coding for the $5-\mathrm{HT}_{1 \mathrm{~A}}$ receptor, a binding site (DRE element) for a specific repressor of this gene was detected [27]. Later, transcription factor Freud-1 (encoded by the Cc2d1a/Freud-1 gene) was identified, which binds to the DRE element in the promoter of the $5-\mathrm{HT}_{1 \mathrm{~A}}$ receptor gene thereby suppressing this gene's expression in the brain [28]. It is now known that Cc2d1a/Freud-1 and Cc2d1b/Freud-2 (a homolog of Cc2d1a/Freud-1) mediate dual repression of 5- $\mathrm{HT}_{1 \mathrm{~A}}$ receptor expression in most cell types, including many postsynaptic neurons. On the basis of its activities in RN46A cells and its localization in 5-HT neurons in vivo, Cc2d1a/Freud-1 is believed to serve as a dominant repressor of $5-\mathrm{HT}_{1 \mathrm{~A}}$ autoreceptor expression [6]. Studies on the role of Cc2d1a/Freud-1 gene overexpression in the 5-HT system suggest that this gene's product potentially plays a part in the regulation of $5-\mathrm{HT}_{1 \mathrm{~A}}$ receptors in anxiety and major depression [28]. Knockouts of the Cc2d1a/Freud-1 gene have been shown to be lethal [29-31]. In $c F 1 k o$ mice (featuring a conditional knockout of Cc2d1a/Freud-1 in 5-HT neurons), the loss of $C \mathrm{c} 2 \mathrm{~d} 1 \mathrm{a} /$ Freud-1 in raphe nuclei in adult animals leads to overexpression of $5-\mathrm{HT}_{1 \mathrm{~A}}$ autoreceptors and correlates with higher $5-\mathrm{HT}_{1 \mathrm{~A}}$ receptor functional activity and with lower 5-HT levels. cF1ko mice show anxiety- and depression-like behavior that is resistant to chronic treatment with an antidepressant (fluoxetine) [32].

It has been suggested that alterations in transcriptional regulation of the $5-\mathrm{HT}_{1 \mathrm{~A}}$ receptor gene may underlie its dysregulation in mental disorders. Albert and coauthors have proposed that transcriptional downregulation of $5-\mathrm{HT}_{1 \mathrm{~A}}$ autoreceptors is among the reasons for the 3-week delay in the clinical response to antidepressant treatment $[16,33,34]$. Consistently with this hypothesis, transgenic mice with $30 \%$ repression of $5-\mathrm{HT}_{1 \mathrm{~A}}$ autoreceptors display an enhanced and rapid response to selective serotonin reuptake inhibitors (SSRIs) [11], suggesting that transcriptional repression of the 5- $\mathrm{HT}_{1 \mathrm{~A}}$ autoreceptor is key to an effective clinical response to an antidepressant [6]. Nevertheless, until now, the 5- $\mathrm{HT}_{1 \mathrm{~A}}$ receptor has not been regarded as an independent target of new-generation antidepressants.

On the other hand, it is well known that the majority of prescribed antidepressants (upon chronic use) are capable of increasing brain-derived neurotrophic factor (BDNF) levels, which is apparently a part of their therapeutic action. The mechanisms of this phenomenon remain unknown [35]. The 5- $\mathrm{HT}_{1 \mathrm{~A}}$ receptor may be among the drug targets responsible for the antidepressant-induced overexpression of BDNF. These assumptions are consistent with evidence of a positive (therapeutic) effect of $5-\mathrm{HT}_{1 \mathrm{~A}}$ receptor activation by antidepressants (e.g., vilazodone) on the BDNF level in depressive disorders [36]. BDNF is synthesized as a precursor, preproBDNF, in the endoplasmic reticulum; then, it is processed and transported as proBDNF to the Golgi apparatus, where after proteolytic cleavage, it is converted into mature BDNF with simultaneous removal of a pro-peptide [37,38]. ProBDNF can also be secreted by the cell independently. Both proBDNF and BDNF exert functional actions, although BDNF binds to receptor TrkB and causes protein synthesis, axon growth, dendrite maturation, and synaptic-plasticity enhancement [38], whereas proBDNF inhibits neurite growth, reduces neuron size, and initiates apoptosis processes through receptor $\mathrm{p} 75^{\mathrm{NTR}}$ via JNK $[39,40]$.

The cross-talk between the 5-HT system and BDNF seems to be crucial for their functioning and regulation of various physiological processes [41,42]. It can be assumed that the inter-relation between the 5-HT system and BDNF also involves Cc $2 \mathrm{~d} 1 \mathrm{a} /$ Freud-1 
because the latter is a transcriptional regulator not only for the 5- $\mathrm{HT}_{1 \mathrm{~A}}$ receptor gene but also for genes of many other factors, such as NF-kappa B (NF-kB) [43] and CREB (cAMP response element-binding protein) [44]. proBDNF activates NF- $\mathrm{KB}$ via receptor p75 ${ }^{\mathrm{NTR}}$, promoting cell survival [45]. At the same time, it is known that NF- $\mathrm{kB}$ regulates the transcription of the 5- $\mathrm{HT}_{1 \mathrm{~A}}$ receptor gene [46]. Additionally, BDNF initiates ERKdependent activation of nuclear transcription factor CREB via receptor TrkB [47].

Based on these data, the present study was designed to further clarify the molecular mechanisms of $C c 2 d 1 a /$ Freud-1 involvement in the regulation of the $5-\mathrm{HT}_{1 \mathrm{~A}}$ receptor as well as the role of $C c 2 d 1 a / F r e u d-1$ in behavior and its possible participation in the cross-talk between the 5-HT system and BDNF in C57BL/6J mice. For this purpose, we investigated the impact of a Cc2d1a/Freud-1 knockdown in the hippocampus using adeno-associated virus (AAV) particles carrying a plasmid encoding a small hairpin RNA (shRNA) targeting Cc2d1a/Freud-1 mRNA.

\section{Results}

2.1. The First Set of Experiments (3 Week of Recovery after $A A V$ Administration)

\subsubsection{The Open Field Test}

The Cc2d1a/Freud-1 knockdown in the hippocampus failed to affect the locomotor activity of mice $\left(\mathrm{F}_{1,16}=0.49, p=0.49\right)$ and the time spent in the center of the open field $\left(F_{1,16}=1.06, p=0.32\right.$, Figure 1a). Nine animals were tested in each group.

(a)

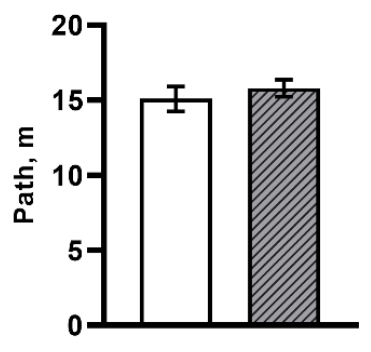

Open field test

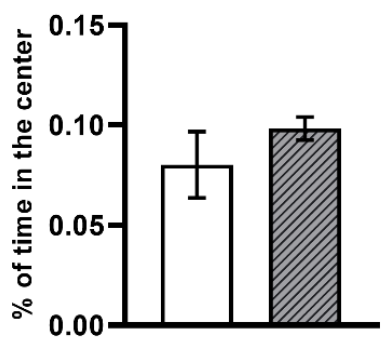

(b) Forced swim test

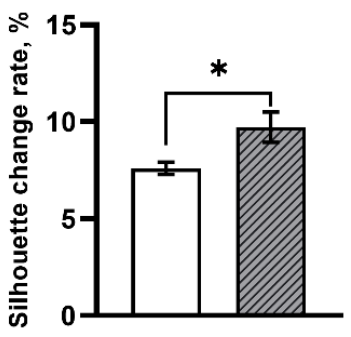

(c)

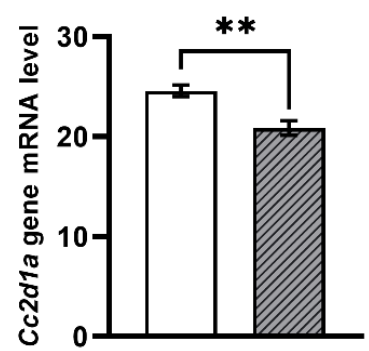

(d)

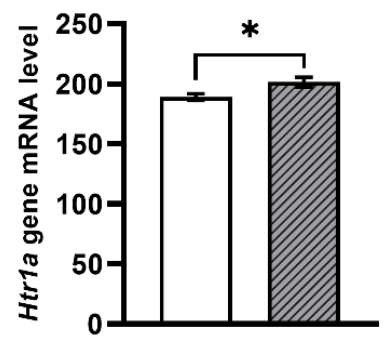

Figure 1. Cc2d1a/Freud-1 downregulation in the hippocampus of mice did not affect locomotor activity and anxiety-like behavior in the open field test (a) while manifesting a significant antidepressant activity in the FST (b) 3 weeks after stereotactic injection. Cc2d1a/Freud-1 (c) and Htr1a (d) mRNA levels in the hippocampus of the experimental mice. Gene expression is presented as the number of cDNA gene copies per 100 cDNA copies of Polr $2 a .{ }^{*} p<0.05 ;{ }^{* *} p<0.01$. N $=7-9$.

\subsubsection{The Forced Swim Test}

The immobility time in the FST is the main parameter of a depressive-like state of an animal because the vast majority of clinically effective antidepressants reduce immobility time and increase active attempts to get out [48]. In our study, we utilized the intensity of the active search-estimated as the rate of change in a mouse's silhouette-as a measure of depressive-like behavior. This parameter negatively correlates with immobility time but is an objective indicator [49]. After 3 weeks of recovery, it was found that the Cc2d1a/Freud-1 
knockdown significantly raised the rate of change in the silhouette (mobility) of the animals $\left(\mathrm{F}_{1,11}=8.56, p<0.01\right)$ as compared to the control group, thus indicating an antidepressant effect of the Cc2d1a/Freud-1 knockdown in the hippocampus (Figure 1b). In both groups, eight animals were tested.

\subsection{3. mRNA Levels}

Cc2d1a/Freud-1 mRNA underexpression $\left(\mathrm{F}_{1,13}=15.32 p<0.002\right)$ was registered in the AAVshRNAFreud1 group compared to the AVVScr mice (Figure 1c). The mRNA level of Htr1a encoding $5-\mathrm{HT}_{1 \mathrm{~A}}$ was higher in the AAVshRNAFreud1 group than in AVVScr mice $\left(\mathrm{F}_{1,13}=6.56 p<0.05\right.$, Figure $\left.1 \mathrm{~d}\right)$. Seven animals were analyzed in the AAVshRNAFreud1 group, and eight animals in the AVVScr group.

As for Polr $2 a$, which served as a housekeeping gene (for normalization), we did not find any difference between the groups $\left(\mathrm{F}_{1,14}=1.92, p=0.19\right)$.

\subsection{The Second and Third Sets of Experiments (5 Week of Recovery after AAV Administration)}

Next, we evaluated the efficiency of the Cc2d1a/Freud-1 knockdown and its ability to change behavior in the FST and in the Morris water maze during a longer period of recovery.

\subsubsection{The Open Field Test}

Five weeks after AAV_SynH1-2_shRNA-Freud-1 injection into the hippocampus, we did not notice its influence on the locomotor activity of mice $\left(\mathrm{F}_{1,18}=0.82, p=0.38\right)$, thereby confirming results of experiment 1 . By contrast, the time spent in the center of the open field was shorter in the AAVshRNAFreud1 group $\left(\mathrm{F}_{1,17}=6.20, p<0.05\right.$, Figure $\left.2 \mathrm{a}\right)$. In both groups, ten animals were tested.

\subsubsection{The Forced Swim Test}

We revealed that the AAVshRNAFreud1 construct led to significant enhancement of the mobility of the animals $\left(\mathrm{F}_{1,18}=21.80, p<0.001\right)$ as compared to the control group, meaning an antidepressant action of the Freud-1 knockdown in the hippocampus (Figure 2b). In both groups, 10 animals were tested.

\subsubsection{Pharmacological Analysis of the $5-\mathrm{HT}_{1 \mathrm{~A}}$ Receptor Functional Activity}

Single i.p. administration of 8-OH-DPAT at a dose of $1 \mathrm{mg} / \mathrm{kg}$ (acute stimulation) had a significant hypothermic effect in both studied groups of mice. The $5-\mathrm{HT}_{1 \mathrm{~A}}$ receptormediated hypothermic response was weaker in the AAVshRNAFreud1 group $\left(\mathrm{F}_{1,14}=3.47\right.$ $p<0.05$ ) than in the AVVScr group (Figure $2 c$ ). In each group, eight mice were analyzed.

\subsubsection{The Morris Water Maze Test}

The impact of the knockdown of the $5-\mathrm{HT}_{1 \mathrm{~A}}$ receptor gene silencer on spatiotemporal memory was investigated in the Morris water maze test. The testing showed that mice in the control group achieved successful results on the fourth day of the test, whereas mice in the AAVshRNAFreud1 group continued to fail when trying to find the platform (Figure 2d).

Repeated-measures ANOVA of the dynamics of memory acquisition uncovered an influence of the test day on the latency of finding the platform $\left(\mathrm{F}_{3,54}=7.84, p<0.01\right)$. Moreover, a significant effect of the test day on the distance traveled to the platform $\left(\mathrm{F}_{3,54}\right.$ $=24.82, p=0.002)$ and the total distance to the platform at each time point $\left(\mathrm{F}_{3,54}=5.67\right.$, $p=0.002$ ) were documented.

The retention day of the test also showed a memory impairment in mice of the experimental group: mice in the AAVshRNAFreud1 group spent less time in the target quarter (where the platform was previously located) as compared to the control group. In each group, 10 animals were tested. 
(a)

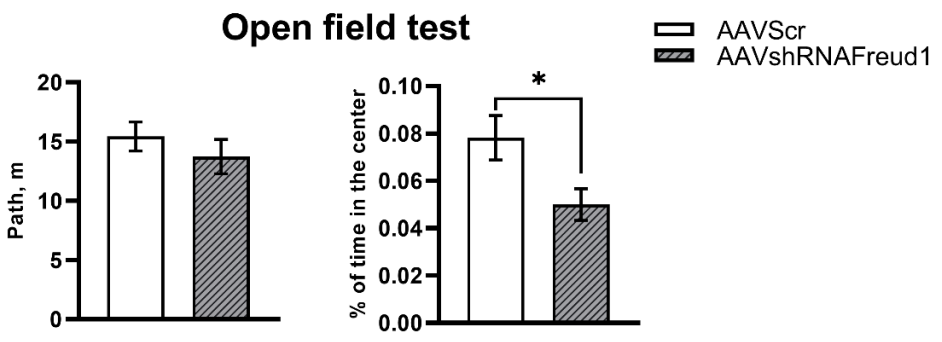

(b) Forced swim test

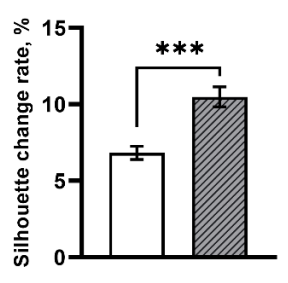

(c) Functional activity of 5- $\mathrm{HT}_{1 \mathrm{~A}}$ receptors

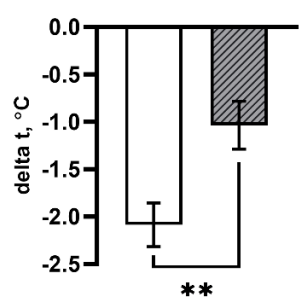

(d)
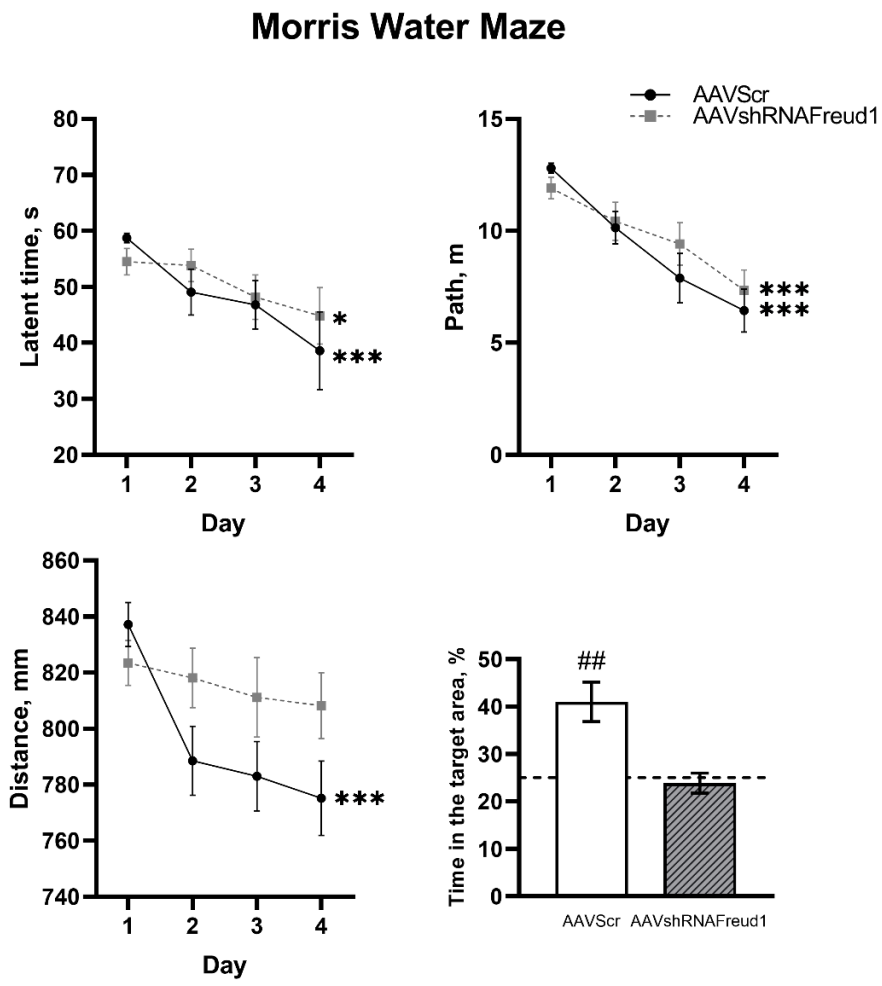

Figure 2. The Cc2d1a/Freud-1 knockdown in the hippocampus of mice 5 weeks after the virus injection exerted an anxiogenic effect in the open field test (a) and a significant antidepressant action in the FST (b); ${ }^{*} p<0.05 ;{ }^{* * *} p<0.001$. The hypothermic response to acute 8-OH-DPAT administration $(1 \mathrm{mg} / \mathrm{kg}$; i.p. injection) was weaker in mice with the Cc2d1a/Freud-1 suppression (c) implying a decrease in $5-\mathrm{HT}_{1 \mathrm{~A}}$ receptor functional activity. ${ }^{* *} p<0.01$. (d) Mice that received AAVshRNAFreud1 failed to find the platform during training and spent less time in the target quarter on the retention day in the Morris water maze test. Dynamics of the cumulative distance alteration between a mouse and the platform, total path, and escape latency during 4 successive days of memory acquisition are presented. ${ }^{*} p<0.05 ;{ }^{* * *} p<0.001$ vs. the first day of memory acquisition. Time spent in the target sector and in the opposite one in the retest were measured as the means of corresponding two trial values. The horizontal line indicates the chance level. \#\# $p<0.01$ vs. the chance level $(25 \%)$. N = 7-10. 


\subsection{5. mRNA, Protein, and Monoamine Levels}

Cc2d1a/Freud-1 mRNA underexpression was documented in the AAVshRNAFreud1 group $\left(\mathrm{F}_{1,15}=10.12, p<0.01\right.$, Figure 3a) compared to AVVScr animals. An influence of the Cc2d1a/Freud-1 knockdown on CC2D1A/Freud-1 protein concentration in the hippocampus $\left(\mathrm{F}_{1,9}=14.74, p<0.005\right)$ was also detected in the AAVshRNAFreud1 group compared to AVVScr mice (Figure $3 b$ ). Additionally, the expression of plasmids was confirmed by fluorescence microscopy of brain slices (Figure 3c).

AAVSCr

AAVshRNAFreud1

(a)

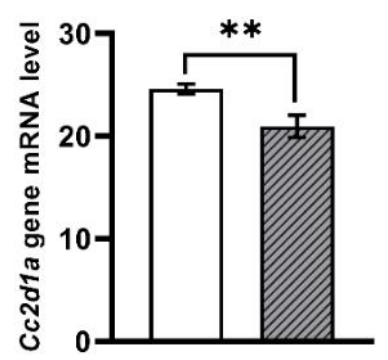

(b)

\section{Freud-1}

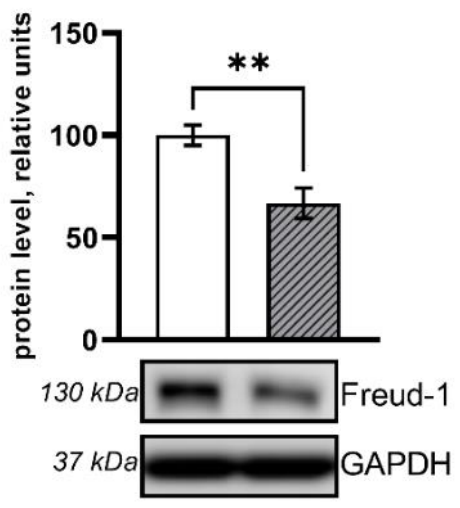

DAPI

(c)
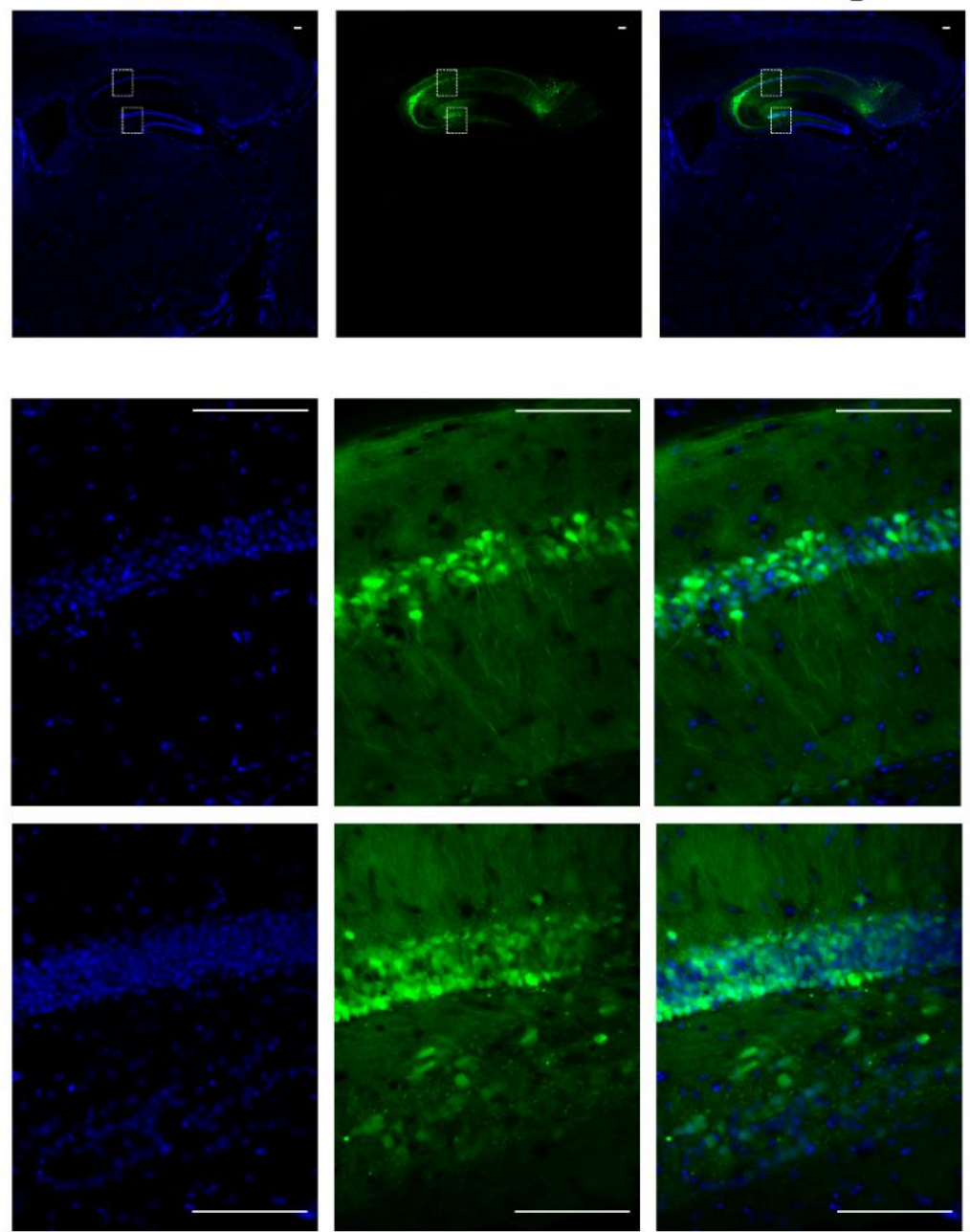

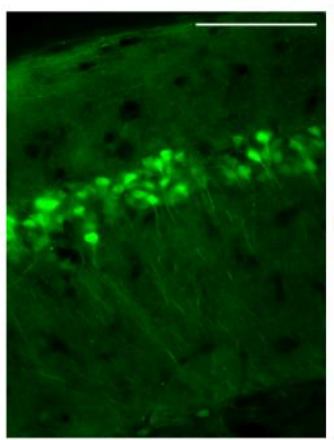

EGFP
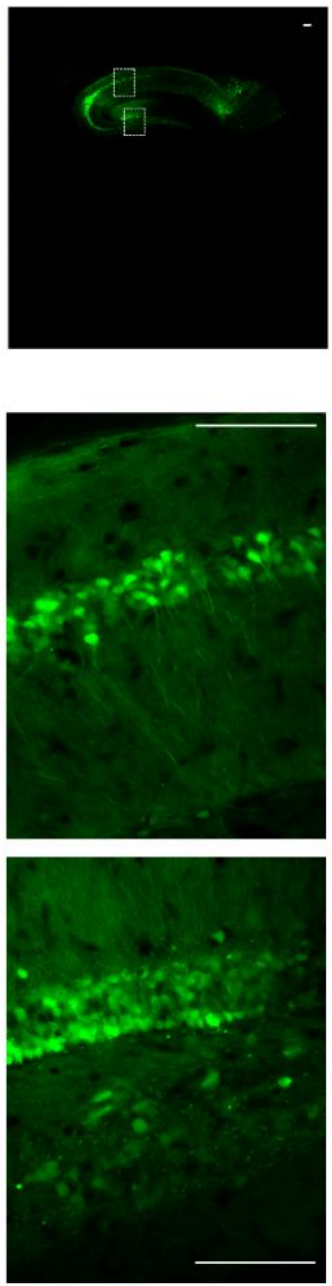

Merge
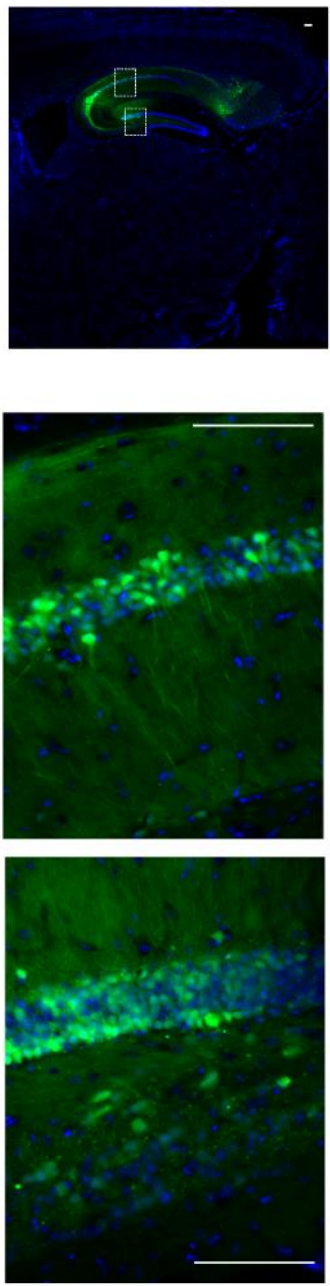

Figure 3. $C c 2 d 1 a /$ Freud-1 mRNA (a) and protein (b) levels in the hippocampus of experimental mice 5 weeks after the virus injection. Successful AAV-mediated transfection is indicated by EGFP expression detectable in cells of the CA1 area and the dentate gyrus (c). Scale bars are $100 \mu \mathrm{m}$. Gene expression is presented as the number of cDNA copies per 100 cDNA copies of Polr2a. The CC2D1A/Freud-1 protein level was assessed in chemiluminescence relative units and normalized to GAPDH chemiluminescence relative units. ${ }^{* *} p<0.01 . \mathrm{N}=8-9$.

In contrast, the Cc2d1a/Freud-1 knockdown failed to affect $\operatorname{Htr} 1 a$ mRNA $\left(\mathrm{F}_{1,15}=0.37\right.$, $p>0.05$, Figure $4 \mathrm{a})$ and protein levels $\left(\mathrm{F}_{1,11}=0.12, p>0.05\right.$, Figure $\left.4 \mathrm{~b}\right)$. 
$\varpi$ AAVScr

(a)

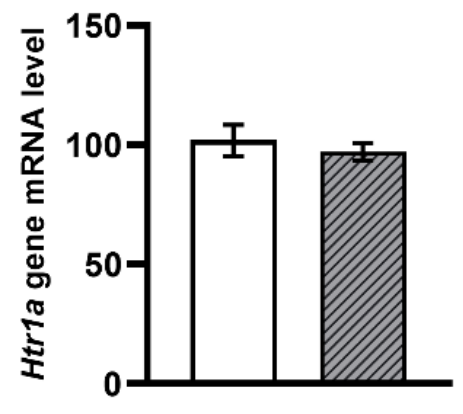

AAVshRNAFreud1

(b)

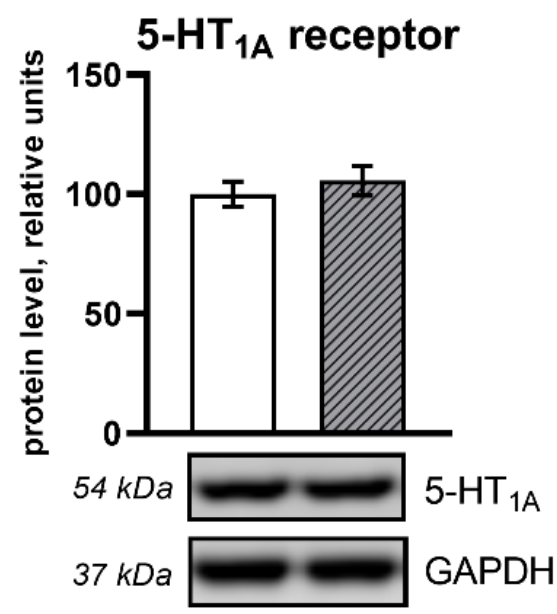

(c)

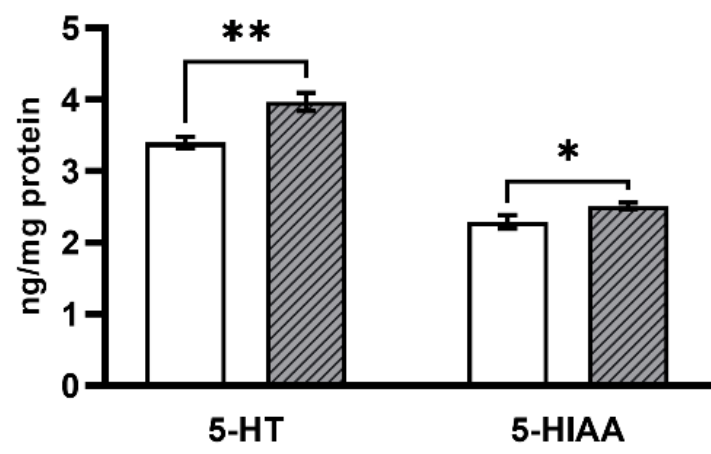

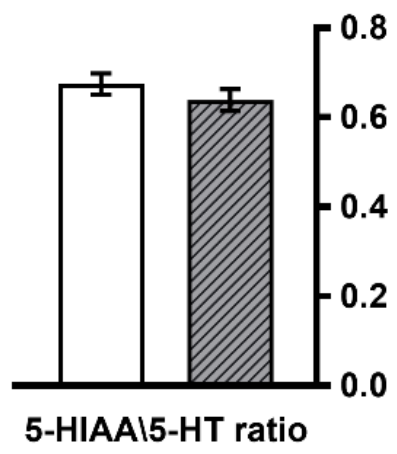

Figure 4. Htr1a mRNA level (a) and protein (b) levels in the hippocampus of experimental and control mice. Gene expression is presented as the number of cDNA copies per $100 \mathrm{cDNA}$ copies of Polr2a. Protein levels were assessed in chemiluminescence relative units and normalized to GAPDH chemiluminescence relative units. (c) The Cc2d1a/Freud-1 knockdown induced an increase in 5-HT and 5-HIAA levels in the hippocampus without changes in the 5-HIAA/5-HT ratio. ${ }^{*} p<0.05$; ${ }^{* *} p<0.01$. $\mathrm{N}=8-9$.

The Cc2d1a/Freud-1 knockdown resulted in considerable changes of concentrations of 5-HT and its metabolite 5-hydroxyindoleacetic acid (5-HIAA) in the mouse hippocampus. An increase in the 5-HT level in mice of the AAVshRNAFreud1 group was demonstrated as compared to AAVScr mice $\left(\mathrm{F}_{1,15}=12.99, p<0.05\right.$, Figure $\left.4 \mathrm{c}\right)$. The 5-HIAA level was also higher in the AAVshRNAFreud1-treated mice $\left(\mathrm{F}_{1,15}=4.58, p<0.05\right.$, Figure $\left.4 \mathrm{c}\right)$. Nevertheless, there was no influence of the Cc2d1a/Freud-1 knockdown on the 5-HIAA/5-HT ratio $\left(\mathrm{F}_{1,15}=1.11, p>0.05\right.$, Figure $\left.4 \mathrm{c}\right)$.

The mRNA and protein levels of Tryptophan hydroxylase-2 (Tph2) gene did not differ between the two groups $\left(\mathrm{F}_{1,16}=0.05, p>0.05\right.$ for Tph 2 mRNA, $\mathrm{F}_{1,12}=0.31, p>0.05$ for TPH2 protein level, Figure $5 a, b)$. The mRNA and protein levels of Monoamine oxidase A (Maoa) gene were not affected either $\left(\mathrm{F}_{1,17}=2.6, p>0.05\right.$ for Maoa $\mathrm{mRNA}_{1,12}=0.22$, $p>0.05$ for MAOA protein level, Figure $5 \mathrm{c}, \mathrm{d})$. 


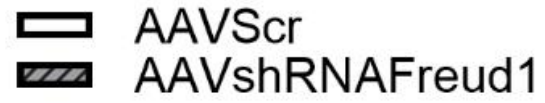

(a)

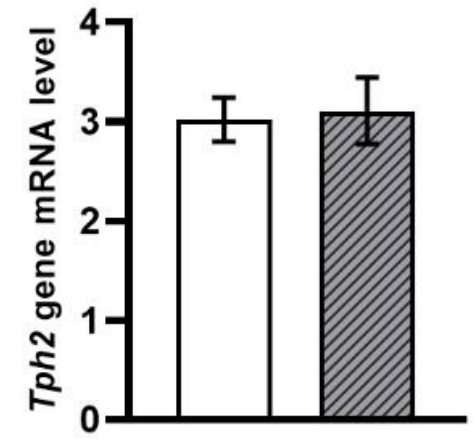

(b)

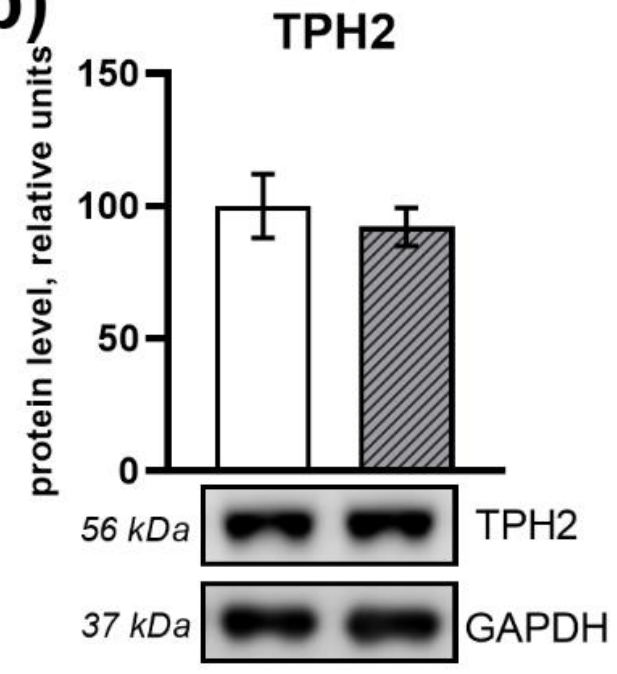

(c)

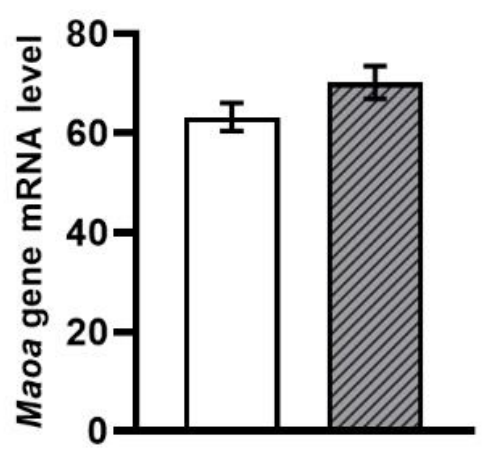

(d)

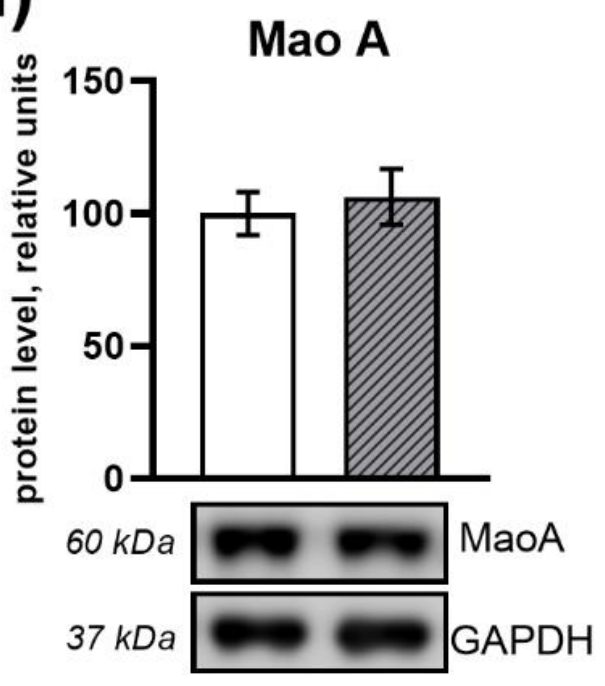

Figure 5. Tph 2 mRNA level (a) and protein (b) levels. Maoa mRNA level (c) and protein (d) levels in the hippocampus of experimental and control mice. Gene expression is presented as the number of cDNA copies per 100 cDNA copies of Polr2a. Protein levels were assessed in chemiluminescence relative units and normalized to GAPDH chemiluminescence relative units. $\mathrm{N}=7-9$.

The Creb mRNA level and CREB phosphorylation were lower in mice of the AAVshRNAFreud1 group $\left(\mathrm{F}_{1,15}=6.08, p<0.05\right.$, for Creb $\mathrm{mRNA}$ and $\mathrm{F}_{1,11}=6.11, p<0.05$, for CREB phosphorylation, Figure $6 \mathrm{a}, \mathrm{b})$, whereas the $c$ Fos mRNA level was higher in these animals $\left(\mathrm{F}_{1,15}=19.77, p<0.001\right.$, Figure 6e). Rela (encoding subunit P65 of NFKB factor) and $N f k b 1$ (encoding subunit P50 of NFKB factor) mRNA levels were not different between the two groups $\left(\mathrm{F}_{1,15}=0.60, p>0.05\right.$, for Rela and $\mathrm{F}_{1,15}=0.13, p>0.05$, for Nfkb1, Figure $\left.6 \mathrm{c}, \mathrm{d}\right)$. 
(a)

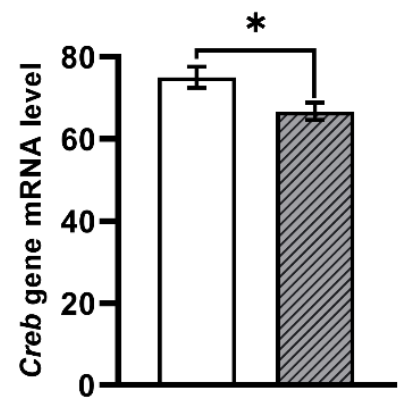

(b) CREB phosphorylation

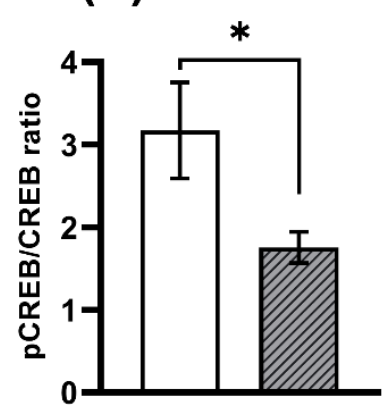

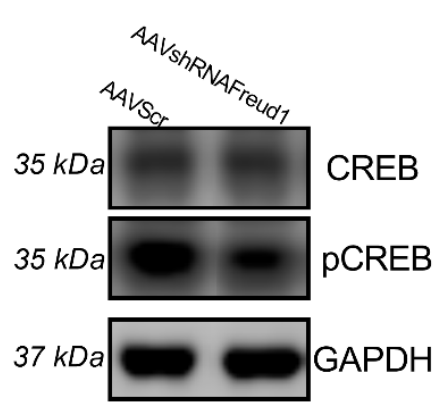

(c)

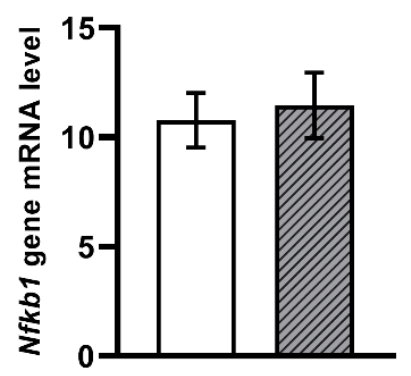

(d)

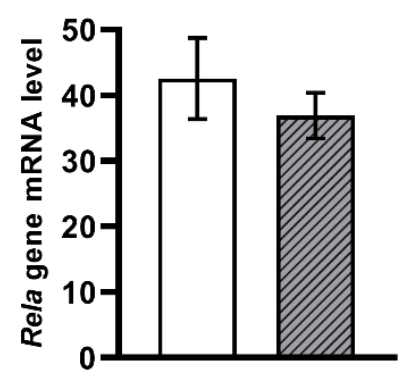

(e)

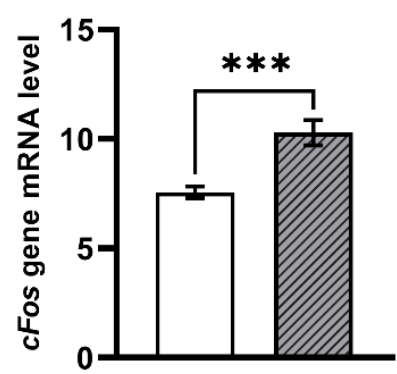

Figure 6. The Cc2d1a/Freud-1 knockdown decreased both the Creb mRNA level (a) and CREB phosphorylation (b). At the same time, the mRNA level of $c F$ os was higher in the mice with the Cc2d1a/Freud-1 knockdown (e). mRNA levels of genes Ntrkb1 (c) and Rela $(\mathbf{d})$ remained unchanged. Gene expression is presented as the number of cDNA copies per 100 cDNA copies of Polr2a. Protein levels were assessed in chemiluminescence relative units and normalized to GAPDH chemiluminescence relative units * $p<0.05 ;{ }^{* * *} p<0.001 . \mathrm{N}=8-9$.

The $B d n f$ mRNA level did not differ between the two groups $\left(\mathrm{F}_{1,15}=0.06, p>0.05\right.$, Figure 7a). Nonetheless, it was noticed that the Cc2d1a/Freud-1 knockdown upregulated proBDNF $\left(\mathrm{F}_{1,10}=12.9, p<0.005\right.$, Figure $\left.7 \mathrm{~b}\right)$. There was no effect of the Cc2d1a/Freud-1 knockdown on the BDNF protein in the hippocampus $\left(\mathrm{F}_{1,10}=0.81, p>0.05\right.$, Figure $\left.7 \mathrm{c}\right)$.

Expression of Ntrk2 (encoding TrkB) and Ngfr (coding for p75 ${ }^{\mathrm{NTR}}$ ) did not differ between the two groups $\left(\mathrm{F}_{1,15}=0.42\right.$ for $N$ trk 2 and $\mathrm{F}_{1,16}=1.31$ for $N g f r, p>0.05$, Figure $\left.7 \mathrm{~d}, \mathrm{e}\right)$. Protein levels of receptors TrkB and $\mathrm{p} 75^{\mathrm{NTR}}$ were not affected either $\left(\mathrm{F}_{1,10}=1.23\right.$ for TrkB and $F_{1,11}=1.01$ for $p 75^{\mathrm{NTR}}, p>0.05$, Figure $\left.7 \mathrm{f}, \mathrm{g}\right)$. As for Polr $2 a$, which served as a housekeeping gene, we did not find any difference between the groups $\left(\mathrm{F}_{1,16}=0.03\right.$, $p=0.87)$.

In the qPCR, HPLC assays and Western blot analysis, eight animals were used from the AAVshRNAFreud1 group, and nine animals from the AVVScr group. 

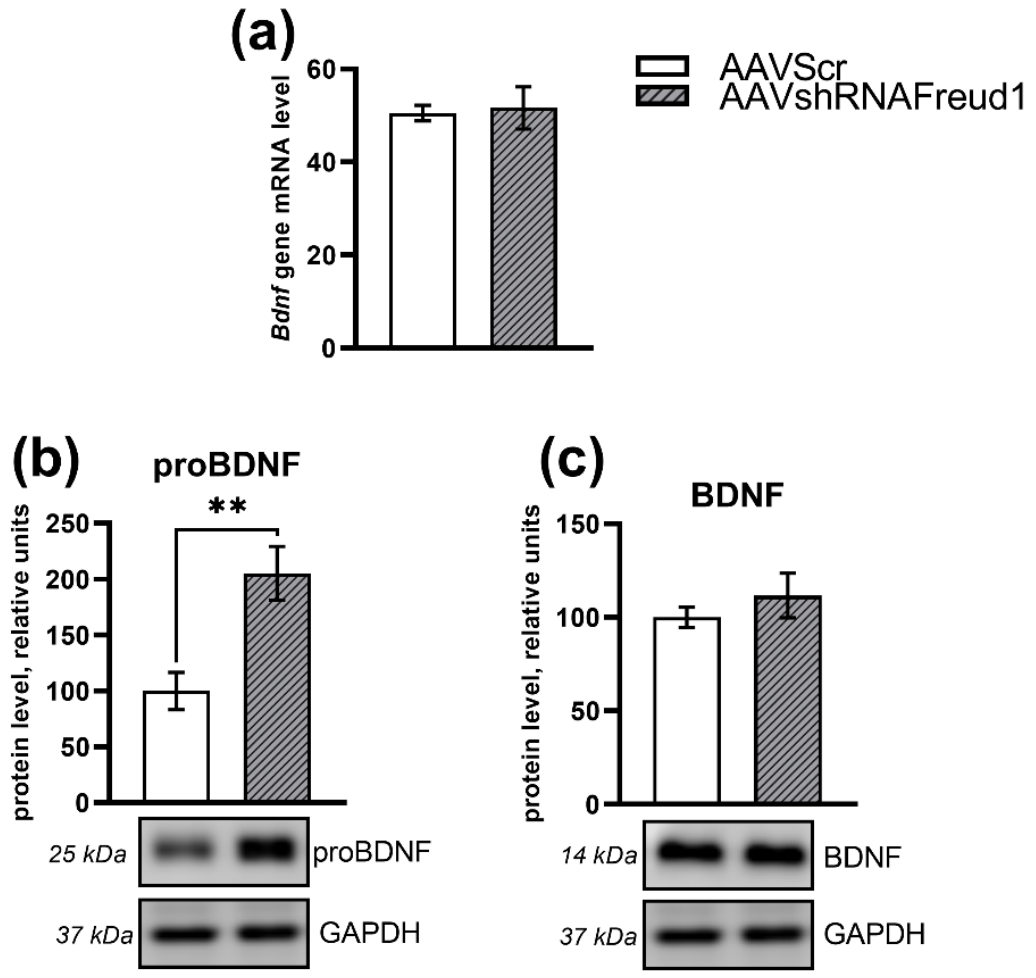

(d)

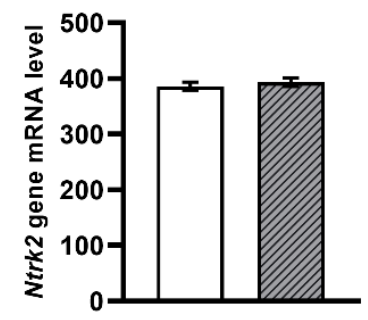

(f)

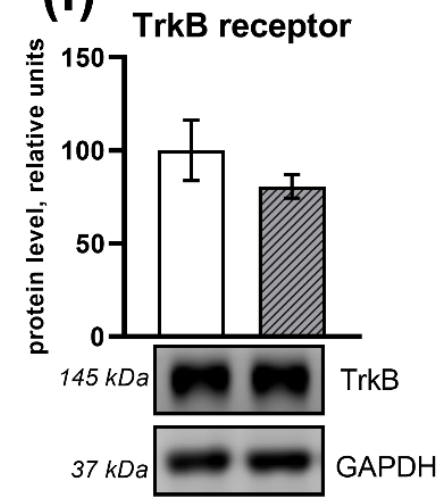

(e)

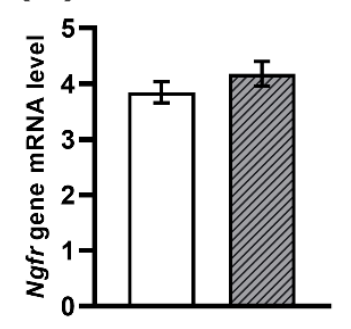

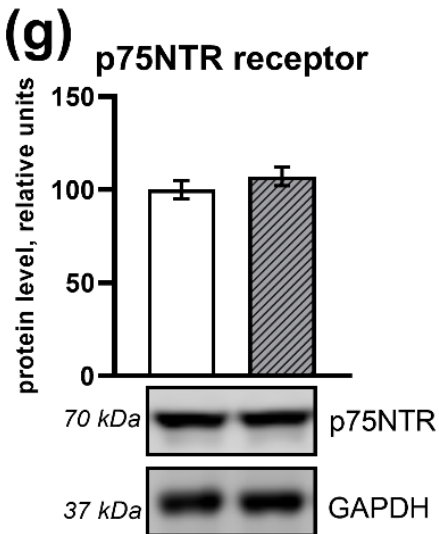

Figure 7. The mRNA level of $B \operatorname{dnf}(\mathbf{a})$ as well as proBDNF (b) and mature BDNF (c) protein levels and mRNA levels of Ntrk2 (d) and Ngfr (e) with protein levels of receptors TrkB (f) and p75 ${ }^{\mathrm{NTR}}(\mathbf{g})$ in the hippocampus of the experimental and control mice. Gene expression is presented as the number of cDNA copies per $100 \mathrm{cDNA}$ copies of Polr2a. Protein levels were assessed in chemiluminescence relative units and normalized to GAPDH chemiluminescence relative units. ${ }^{* *} p<0.01$. $\mathrm{N}=8-9$. 


\section{Discussion}

Some data indicate that the $5-\mathrm{HT}_{1 \mathrm{~A}}$ receptor is among major drug targets mediating SSRI-induced adult hippocampal neurogenesis: SSRIs do not enhance neurogenesis in $5-\mathrm{HT}_{1 \mathrm{~A}}$ receptor knockout mice [50]. In the present study, we focused on the Cc2d1a/Freud-1 involvement in the regulation of the $5-\mathrm{HT}_{1 \mathrm{~A}}$ receptor and its function in behavioral plasticity as well as in 5-HT-BDNF cross-talk. For the first time, we showed that Cc2d1a/Freud-1 downregulation increases mobility in the FST after 3 weeks. Due to classic antidepressants, including those currently prescribed in the clinic, significantly enhancing the mobility of animals in this test [51], the observed CC2D1A/Freud-1-dependent behavioral effect may be considered antidepressive. These behavioral changes were accompanied by a significant reduction in Cc2d1a/Freud-1 gene expression and, as expected, by Htr1a overexpression.

A similar behavioral impact of the Cc2d1a/Freud-1 knockdown was observed in the second set of experiments 5 weeks after the AAV administration. In addition, mRNA and protein levels of Cc2d1a/Freud-1 were significantly lower compared to those in the control group. Nonetheless, there were no changes in Htr1a mRNA and its protein level after the Cc2d1a/Freud-1 knockdown. It can be assumed that during a longer recovery period, a feedback mechanism restores the expression of the $5-\mathrm{HT}_{1 \mathrm{~A}}$ receptor to its baseline. Moreover, other mechanisms and brain systems may be involved in behavior regulation in the FST.

We showed that the partial Cc2d1a/Freud-1 downregulation in the hippocampus resulted in a spatiotemporal memory disturbance as assessed in the Morris water maze; in the retention test, the mice spent less time in the target quarter. These data are in agreement with the results of Oak et al. and Yang et al. [52,53], who documented a disturbance in spatial learning and memory in mice with a conditional Cc2d1a/Freud-1 knockout. Several studies imply that the dorsal hippocampus and ventral hippocampus have different functions; the former is involved in cognition, while the latter is more important for the regulation of affective states [54]. For instance, dorsal hippocampus lesions in rats worsen spatial memory in the Morris water maze and radial arm maze [55,56]. Meanwhile, it has been reported that systemic administration of 8-OH-DPAT impairs spatial memory acquisition in the Morris water maze $[57,58]$, and this alteration is abrogated by $5-\mathrm{HT}_{1 \mathrm{~A}}$ receptor antagonists [59-61]. Stimulation of the 5- $\mathrm{HT}_{1 \mathrm{~A}}$ receptor by $8-\mathrm{OH}-\mathrm{DPAT}$ infusion into the CA1 region of the dorsal hippocampus impairs spatial discrimination in rats [60]. Therefore, our results on the $C c 2 d 1 a /$ Freud-1 suppression-induced impairment of spatiotemporal memory are in good agreement with literature data on the involvement of $5-\mathrm{HT}_{1 \mathrm{~A}}$ receptors in memory and learning mechanisms [62].

We found that in the AAVshRNAFreud1 group, levels of 5-HT and its metabolite 5-HIAA were higher, although the 5-HIAA/5-HT ratio reflecting serotonin catabolism was unchanged. It is obvious that the absence of an influence on the 5-HIAA/5-HT ratio is attributable to enhanced 5-HT catabolism reflected in the higher 5-HIAA level. Overall, our results are consistent with the reports of initial 5-HT upregulation and a return to baseline or even lower levels after prolonged SSRI treatment [63-65]. It is known that SSRIs can raise the extracellular level of 5-HT by inhibiting its reuptake into the presynaptic cell, thereby leading to better neurotransmission and improved mood [66]. Similarly, it is possible that the positive impact of the Cc2d1a/Freud-1 knockdown in the hippocampus on the behavior in the FST is mediated by $5-\mathrm{HT}_{1 \mathrm{~A}}$ receptor-dependent changes in serotonin reuptake or via altered activity of a catabolic enzyme since no changes were found in the expression of the tryptophan hydroxylase-2 (key enzyme for 5-HT biosynthesis in the brain) and the monoamine oxidase type A (enzyme for 5-HT degradation).

Furthermore, we propose that at 3 weeks after the AAV administration, the knockdown of the Cc2d1a/Freud-1 gene has an antidepressant effect reflected in higher mobility in the FST via overexpression of the Htr1a gene in the hippocampus. In 5 weeks, the antidepressant action persisted due to the higher level of 5-HT and most likely because of the decreased functional response of the $5-\mathrm{HT}_{1 \mathrm{~A}}$ presynaptic autoreceptor. Although the $5-\mathrm{HT}_{1 \mathrm{~A}}$ receptor-mediated hypothermic response is believed to be mediated by the 
postsynaptic 5- $\mathrm{HT}_{1 \mathrm{~A}}$ receptor [67], there is some evidence for the participation of $5-\mathrm{HT}_{1 \mathrm{~A}}$ autoreceptors in the mechanisms underlying 8-OH-DPAT-induced hypothermia $[68,69]$. Moreover, it has been suggested that the $5-\mathrm{HT}_{1 \mathrm{~A}}$ receptors-mediated hypothermia may be related to those involved in depression and anxiety [70]. It has been demonstrated that rats of the HDS (high 8-OH-DPAT sensitivity) strain exhibit more pronounced immobility in the FST [71] and heightened anxiety in some other tests [72,73]. Chronic antidepressant treatment downregulates $5-\mathrm{HT}_{1 \mathrm{~A}}$ receptor function, judging from 8-OH-DPAT-induced hypothermia $[74,75]$.

Attenuated 8-OH-DPAT-induced hypothermic response observed in mice from Cc2d1a/Freud-1 knockdown group was not accompanied by corresponding changes in 5$\mathrm{HT}_{1 \mathrm{~A}}$ receptor expression that is not much of a surprise since $5-\mathrm{HT}_{1 \mathrm{~A}}$ receptor function is depend on a dynamic balance of their production, activation, internalization, and recycling to the plasma membrane in inactivated (desensitized) form [4,76]. Additionally, $5-\mathrm{HT}_{1 \mathrm{~A}}$ receptor is known to be modified posttranslationally [77] and could interact with other 5 -HT receptors [78-80] that greatly affect receptor function. Moreover, a previous study has suggested that activation of $5-\mathrm{HT}_{1 \mathrm{~A}}$ receptor in the preoptic anterior hypothalamus may be important in the induction of hypothermia [81]. The current data suggest that hippocampal $5-\mathrm{HT}_{1 \mathrm{~A}}$ receptors may be important for thermoregulation as well.

The involvement of the brain 5-HT system and BDNF in the mechanisms behind depressive behavior as well as their mutual regulation are well established [41,42]. BDNF is thought to be intimately involved in the pathogenesis of many disorders of the nervous system, including depression [82-88]. Here we found that the knockdown of Cc2d1a/Freud-1 in the hippocampus increased the proBDNF level. The results of our study suggest that BDNF is implicated in the antidepressant-like response (induced by hippocampal CC2D1A/Freud1 downregulation) through mechanisms involving other transcription factors such as CREB. The latter is one of the key players in the control of expression of immediate early genes. The CRE $\left(\mathrm{Ca}^{2+} / \mathrm{cAMP}\right.$-responsive element) site is present in the promoter regions of almost all neuronal immediate early genes including cFos and $B d n f$ [89]. Bdnf transcription is directly enhanced by CREB [90]. However, here we revealed that the knockdown of Cc2d1a/Freud-1 in the hippocampus reduces the expression of the Creb gene and CREB phosphorylation at the protein level. Our findings are consistent with the data of Zamarbide and coauthors who demonstrated that $C c 2 d 1 a /$ Freud-1 deficiency in male mice leads to a reduction in CREB signaling [44]. They have also demonstrated that CC2D1A/Freud-1 regulates CREB activation in hippocampal neurons by increasing activity of phosphodiesterase PDE4D, an enzyme involved in cAMP degradation [44]. Earlier, it was shown that spatial memory deficits have been linked to reduced CREB activation in the hippocampus [91]. Together these results explain our data on the Cc2d1a/Freud-1 knockdown-induced spatiotemporal learning and memory impairment.

cFos is considered a marker of plastic changes during memory formation because its activation is triggered by higher neuronal activity, and its products play an essential role in plasticity [92]. We noted a higher $c$ Fos mRNA level after the Cc2d1a/Freud-1 knockdown in the hippocampus. It can be assumed that this increase is a response to CREB underexpression or/and could be related to proBDNF protein upregulation. Since Cc2d1a/Freud-1 knockdown increased proBDNF level without affecting its mRNA, it can be suggested that $C c 2 d 1 a / F r e u d-$ 1 may affect (via CREB or other pathways) enzymes involved in the proBDNF processing from preproBDNF. On the other hand, it may be directly related to a decrease of 5-HT $\mathrm{HT}_{1 \mathrm{~A}}$ receptors' functional activity because their activation is reported to diminish the cFos level [93].

It is known that Cc2d1a/Freud-1 encodes a multifunctional signaling factor, CC2D1A/Freud-1, which regulates multiple pathways taking part in neuronal differentiation by linking transmembrane receptors and their downstream effectors, including protein kinase $\mathrm{B}$ ( $\mathrm{PKB} / \mathrm{AKT})$ activators [94] as well as multiple upstream effectors for transcription factor NF- $\mathrm{kB}$ activation $[95,96]$. In turn, NF- $\mathrm{kB}$ activation also depends on $5-\mathrm{HT}_{1 \mathrm{~A}}$ receptor triggering [97]. At the same time, proBDNF activates NF- $\mathrm{kB}$ via $\mathrm{p} 75^{\mathrm{NTR}}$, promot- 
ing cell survival [45]. Nevertheless, we failed to detect an influence of the Cc2d1a/Freud-1 suppression in the hippocampus on RelA and $N f k b 1$ mRNA levels, although it had been shown earlier that both a gain and loss of CC2D1A/Freud-1 function activate NF- KB in developing neurons [98]. Our results mean that the knockdown of Cc2d1a/Freud-1 in the hippocampus is not sufficient to alter the NF-KB signaling pathway in vivo.

\section{Materials and Methods}

4.1. Experimental Design

\subsubsection{Animals}

All experiments were carried out on adult male mice of the C57BL/6J inbred strain. The mice were housed under standard laboratory conditions on a natural light-dark cycle ( $12 \mathrm{~h}$ light and $12 \mathrm{~h}$ dark) with free access to water and feed. Two days before behavioral testing, the mice were weighed (their average weight turned out to be $\sim 25 \mathrm{~g}$ ) and were isolated in individual cages to prevent group effects $[99,100]$. The cost of keeping animals was supported by basic-research project No. 0259-2021-0015 and was implemented using the equipment of the Center for Laboratory Animal Genetic Resources at the ICG SB RAS with support from the Ministry of Science and Higher Education of the Russian Federation (project No. RFMEFI62117X0015). All experimental procedures complied with the Guide for the Care and Use of Laboratory Animals, Eighth Edition, Committee for the Update of the Guide for the Care and Use of Laboratory Animals (National Research Council @ 2011 National Academy of Sciences, Washington, DC, USA).

\subsubsection{Plasmids}

The sequences of shRNAs against Cc2d1a/Freud-1 mRNA were as follows:

sense $5^{\prime}$-gatccccagatacctctgaggctgtcttcaagagagacagcctcagaggtatcttttttttggaaag- $3^{\prime}$; antisense $5^{\prime}$-tcgactttccaaaaaaagatacctctgaggctgtctctctctgaagacagcctcagaggtatctggg- $3^{\prime}$.

The annealed double-stranded oligo was inserted at BgIII and SalI sites in the multiple cloning region of the pAAV-Syn-EGFP-H1-2 vector under the control of the histone H1 promoter [101]. This vector also carries a green fluorescent protein for testing the effectiveness of plasmid expression. All cloning steps were verified by Sanger sequencing. A scrambled shRNA was a gift from Evgeni Ponimaskin (MHH, Hannover, Germany). Both AAV vectors carry the $\mathrm{H} 1$ promoter for the expression of either $C c 2 d 1 a /$ Freud- 1 shRNA or the scrambled control shRNA, whereas EGFP expression is driven by the synapsin promoter (Figure 8a).

\subsubsection{Cell Culture and Transfection}

HEK293FT cells were subcultured in Dulbecco's modified Eagle's medium (DMEM) (Sigma-Aldrich, Burlington, MA, USA) supplemented with 10\% of fetal bovine serum (FBS, Gibco, Carlsbad, CA, USA), $1 \%$ of GlutaMAX (Gibco, Carlsbad, CA, USA), and $1 \%$ of Penicillin-Streptomycin (Gibco, Carlsbad, CA, USA). The cells were incubated at $37^{\circ} \mathrm{C}$ and $5 \% \mathrm{CO}_{2}$. The cells were subcultured at $70 \%$ confluence, and the medium was refreshed every 2-3 days. HEK293FT cells were transfected with plasmids using polyethylenimine (PEI, 23966-2, Polysciences, Warrington, PA, USA), following the manufacturer's instructions.

\subsubsection{AAV Production}

The packaging of pAAV_H1-2_shRNA-Freud-1_Syn_EGFP or of the scrambled-controlshRNA-expressing plasmid into AAV capsids was performed by cotransfection with AAV-DJ and pHelper (Cell Biolabs, Inc., San Diego, CA, USA) plasmids in HEK-293FT cells [101]. Viral particles were harvested after $48 \mathrm{~h}$, according to the protocol described by Grimm et al. [102]. The amount of the obtained viral particles was determined by quantitative PCR (qPCR) with the following primer set: F, 5'-cctggttgctgtctctttatgagg; R, $5^{\prime}$-tgacaggtggtggcaatgc. A series of dilutions of the original plasmid of known concentration served as a standard for determining the number of viral particles. Both AAV vectors used in this study yielded similar genomic titers $\left(10^{9}\right.$ viral genomes per microliter). 
(a)
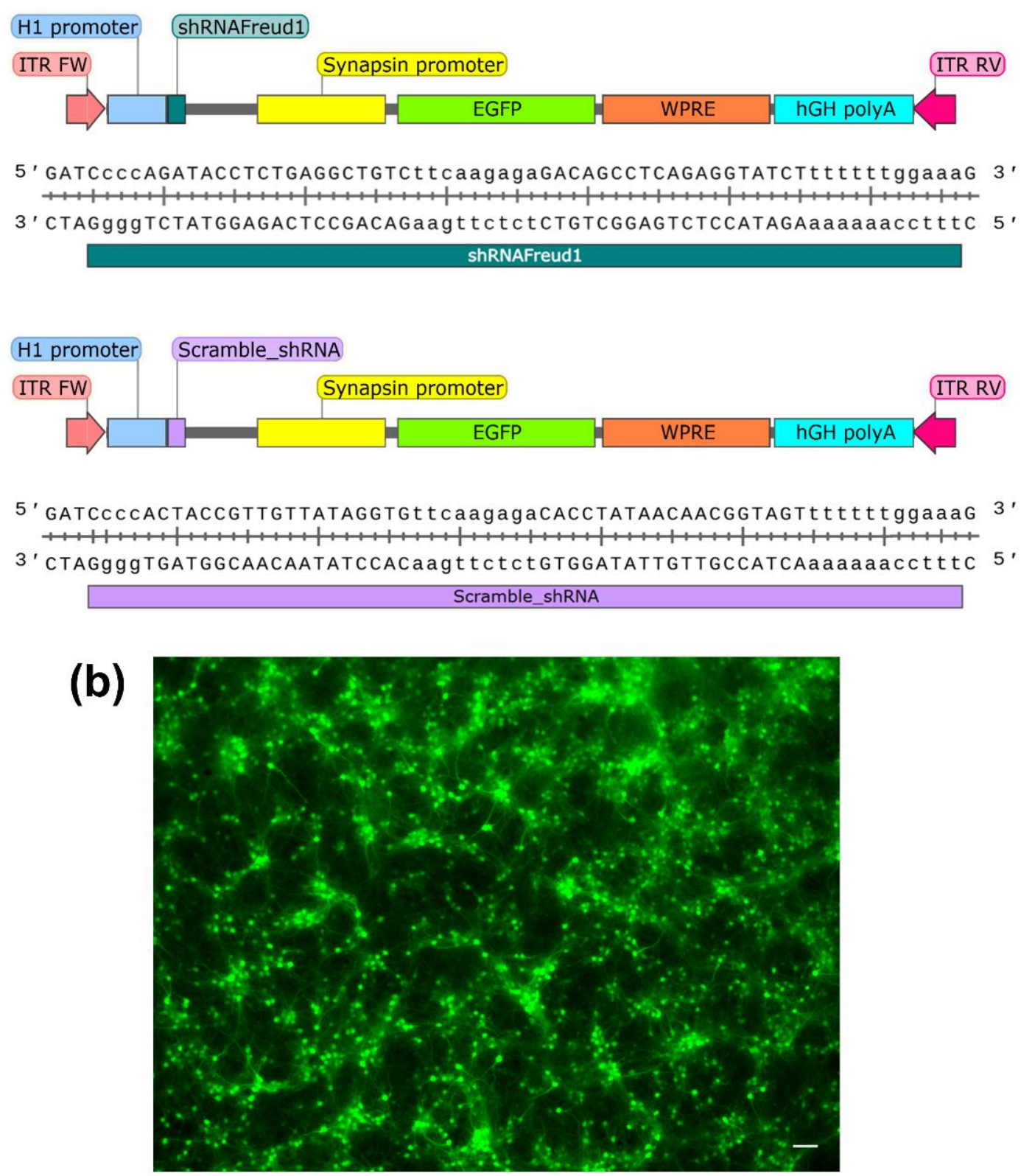

Figure 8. Maps of the AAV vectors (a). ITR, inverted terminal repeat; EGFP, enhanced green fluorescent protein gene; Syn, synapsin promoter; WPRE, woodchuck hepatitis virus post-transcriptional regulatory element; hGH polyA, human growth hormone polyadenylation signal. (b) AAV-mediated infection as indicated by the EGFP expression is detected in primary hippocampal neurons. Scale bars are $100 \mu \mathrm{m}$.

\subsubsection{Primary Neuronal Culture}

Cultures of hippocampal neurons were prepared from C57BL/6J mice on embryonal day 18 according to an optimized protocol for mouse hippocampal neurons [103]. Briefly, hippocampi were excised and digested by trypsin treatment for $20 \mathrm{~min}$. The obtained cell suspension was centrifuged at $200 \mathrm{~g}$ for $3 \mathrm{~min}$. After, dissociated neurons were resuspended in DMEM (Sigma-Aldrich, Burlington, MA, USA) supplemented with 10\% of FBS (Gibco, Carlsbad, CA, USA) and plated on $18 \mathrm{~mm}$ glass coverslips coated with $0.1 \mathrm{mg} / \mathrm{mL}$ poly-d-lysine (Sigma-Aldrich, Burlington, MA, USA). After, $1 \mathrm{~h}$ incubation at $37^{\circ} \mathrm{C}$, the Neurobasal-A medium (Gibco, Carlsbad, CA, USA) that contained $20 \mathrm{mM}$ GlutaMAX supplement (Gibco, Carlsbad, CA, USA), B-27 supplement (Gibco, Carlsbad, CA, USA), and $100 \mathrm{U} / \mathrm{mL}$ penicillin/streptomycin (Sigma-Aldrich, Burlington, MA, USA) was added. The cultures were maintained at $37^{\circ} \mathrm{C}$ in a humidified incubator in an 
atmosphere containing $5 \%$ of $\mathrm{CO}_{2}$. Half of the medium was refreshed every third day. Cell transduction with an AAV vector was performed on the ninth day in vitro. The effectiveness of AVV transduction was demonstrated (Figure $8 b$ ).

\subsubsection{Stereotactic Injection into the Hippocampus}

Mice were anesthetized with $400 \mu \mathrm{L}$ of a 1:1 mixture of 2,2,2-tribromethanol (SigmaAldrich, Burlington, MA, USA) and 2-methyl 2-butanol (Sigma-Aldrich, Burlington, MA, USA) diluted 40-fold in saline and placed in a stereotaxic frame (TSE systems, Bad Homburg, Hessen, Germany). Briefly, the scalp was opened, and two holes were drilled in the skull (AP: $-1.5 \mathrm{~mm}$, ML: $-1.0 \mathrm{~mm}$, DV: $1.5 \mathrm{~mm}$ and AP: $-1.5 \mathrm{~mm}$, ML: $+1.0 \mathrm{~mm}$, DV: $1.5 \mathrm{~mm}$ ) [104]. The viruses carrying pAAV_H1-2_shRNA-Freud-1_Syn_EGFP (group AAVshRNAFreud1) were slowly bilaterally injected ( $1 \mu \mathrm{L}$ per side) into the hippocampus area through a Hamilton syringe at a rate of $0.1 \mu \mathrm{L} / \mathrm{min}$ for $10 \mathrm{~min}$. After the injection, the needle was kept in place for additional $2 \mathrm{~min}$ to minimize any drawback of the virus suspension as the needle was removed. As an appropriate control, the AAV expressing the scrambled control shRNA (group AVVScr) was administered in the same way. After the bilateral injections of the virus, the incision was closed with interrupted silk sutures, and the animal was placed in a warm cage and monitored closely.

In the first set of experiments, after 3 weeks of recovery, we carried out behavioral tests (open field test and forced swim test; FST), fluorescence microscopy and qPCR in order to examine the effect of the plasmid transfection in vivo. Both behavioral tests were conducted with video registration and calculations in the Ethostudio software developed in our laboratory [49]. At least 8 animals from each group were analyzed (Figure 9a).

In the second set of experiments, after 5 weeks of recovery, behavior in the open field test and FST was evaluated (both behavioral tests were conducted with video registration and calculations in the Ethostudio software), a pharmacological analysis of 5- $\mathrm{HT}_{1 \mathrm{~A}}$ receptor functional activity was performed, and hippocampus samples were collected for qPCR and high-performance liquid chromatography (HPLC) assays. In each group, at least 10 animals were analyzed (Figure $9 b$ ).

In the third set of experiments, after 5 weeks of recovery, the Morris water maze test was conducted with video registration and calculations in the Ethostudio software, and hippocampus samples were collected for Western blot. In each group, at least 10 animals were analyzed (Figure 9c).

\subsubsection{Hippocampus Isolation}

At $46-48 \mathrm{~h}$ after behavioral testing, animals were decapitated, and their hippocampi were excised on ice, frozen in liquid nitrogen, and stored at $-80^{\circ} \mathrm{C}$ until qPCR, HPLC, and Western blot experiments were carried out. In the two groups, hippocampi were excised on the same day (12:00-14:00 p.m.).

\subsubsection{The Open Field Test}

This test was carried out in a circular arena ( $40 \mathrm{~cm}$ in diameter) surrounded by a white plastic wall $(25 \mathrm{~cm}$ high) and illuminated through a mat and semitransparent floor with two halogen lamps of $12 \mathrm{~W}$ each placed $40 \mathrm{~cm}$ under the floor [105]. Each mouse was placed near the wall and tested for $5 \mathrm{~min}$. The distance traveled and time spent in the center of the arena were measured. 
(a)

First set of experiments

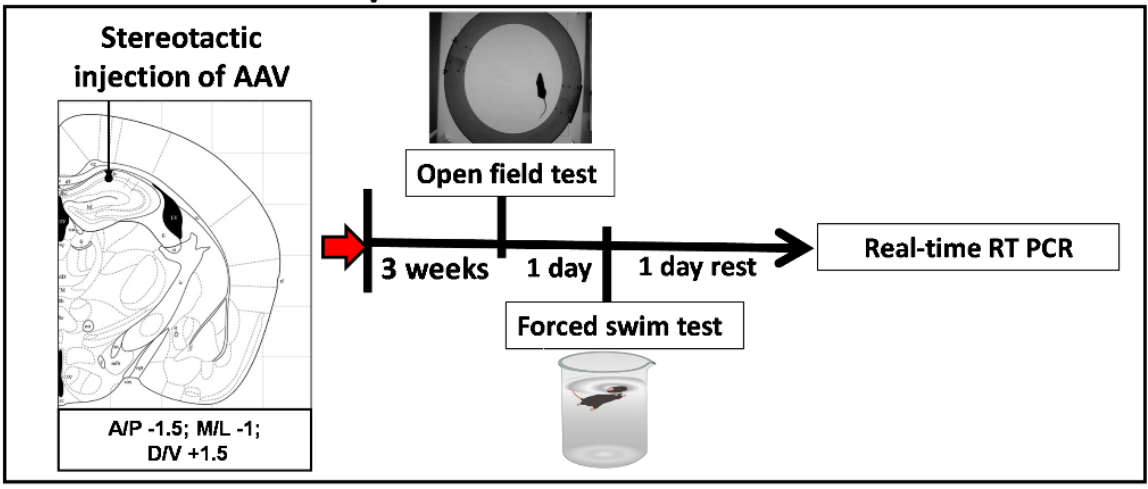

(b)

Second set of experiments

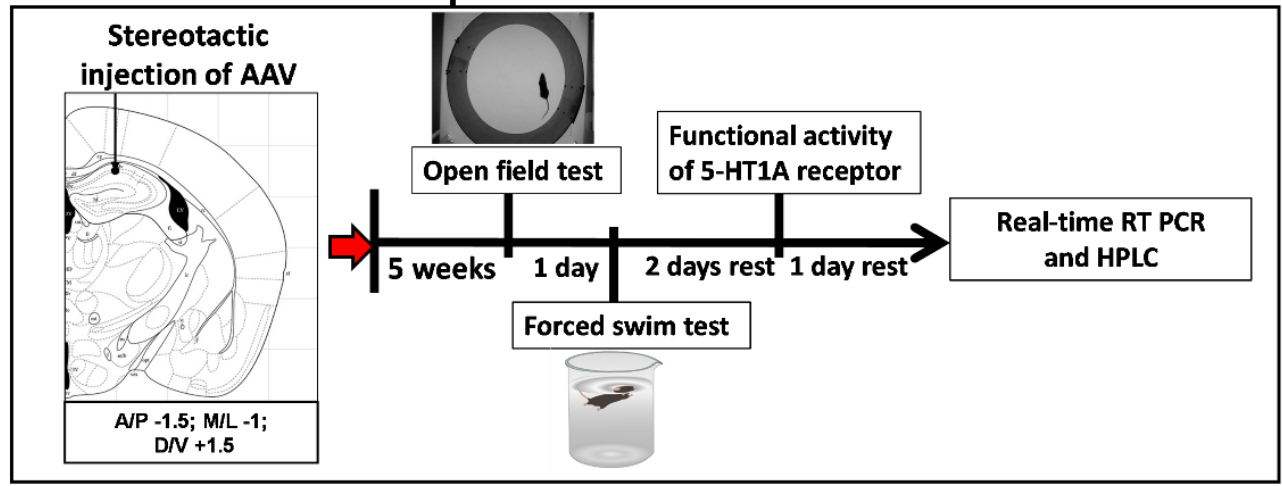

(c)

Third set of experiments

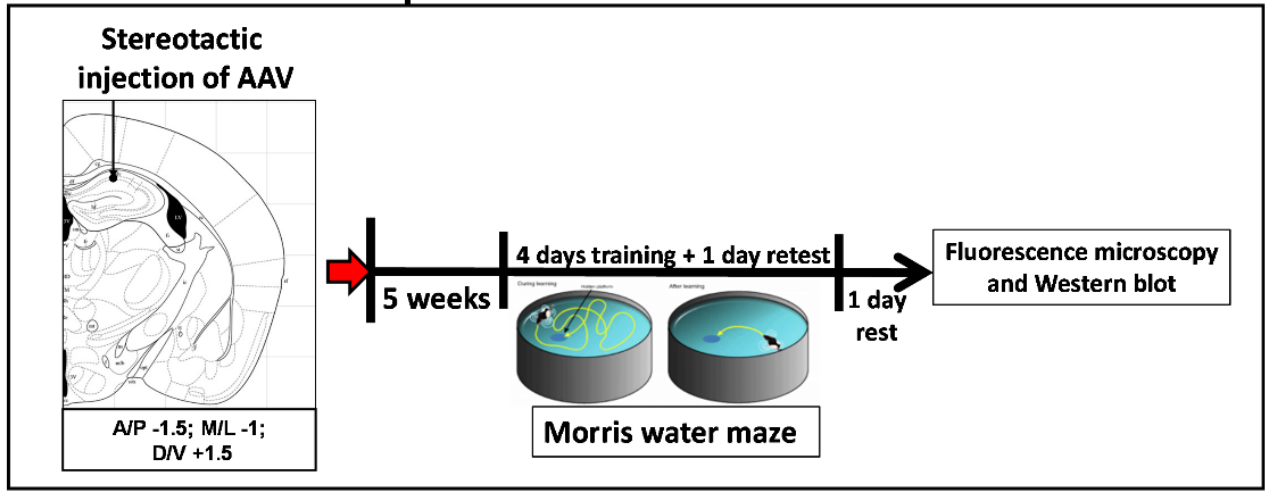

Figure 9. Design of the experiment. (a) First set of experiments. (b) Second set of experiments. (c) Third set of experiments.

\subsubsection{The Forced Swim Test}

Each mouse was placed in a clear plastic box $(30 \times 30 \times 30 \mathrm{~cm})$ filled with water of $25{ }^{\circ} \mathrm{C}$. Mouse mobility was measured for $4 \mathrm{~min}$ (after $2 \mathrm{~min}$ adaptation) by the Ethostudio program. The program measured the rate of change in the silhouette of an animal, which was determined as the number of animal-associated pixels changed between two adjacent frames [106].

\subsubsection{Pharmacological Analysis of 5- $\mathrm{HT}_{1 \mathrm{~A}}$ Receptor Functional Activity}

The functional activity of $5-\mathrm{HT}_{1 \mathrm{~A}}$ receptors was estimated by quantification of the hypothermic response to acute administration of a 5- $\mathrm{HT}_{1 \mathrm{~A}}$ agonist: $( \pm)-8$-Hydroxy-2(dipropylamino)tetralin hydrobromide (8-OH-DPAT; at $1 \mathrm{mg} / \mathrm{kg}$ intraperitoneally [i.p.]) [71,107]. Core temperature of the mice was measured by means of a KJT thermo- 
couple (Hanna Instruments, Singapore) with a copper constantan rectal probe (Physitemp Instruments, Clifton, NJ, USA) before and 20 min after the drug administration.

\subsubsection{The Morris Water Maze Test}

The experiment was conducted as previously described [108]. A circular white plastic tank (100 cm diameter, $40 \mathrm{~cm}$ high) with a mat and semitransparent floor was employed. We tracked each animal by transmitted (inverted)-lighting techniques developed for the open field test [105]. The water $\left(25^{\circ} \mathrm{C}\right)$ was rendered opaque by the addition of nonfat dry milk. The surface of the tank was virtually subdivided into four quadrants. A glass escape round platform ( $5 \mathrm{~cm}$ diameter and $14.5 \mathrm{~cm}$ height) was located $1 \mathrm{~cm}$ below the water surface near the center of the target quadrant of the maze. Each mouse underwent three acquisition trials per day for 4 consecutive days. Trial duration was limited to $60 \mathrm{~s}$. During each training trial, an animal was released into the maze from the fixed start position in the center of the tank. Regardless of whether the mouse found the platform, it was placed on the platform and allowed to stay on it for $15 \mathrm{~s}$. Parameters measured during an acquisition trial included latency to reach the hidden platform (escape latency time, $\mathrm{s}$ ) and the path traveled to the platform $(\mathrm{cm})$. Mean values were calculated from the three trials of the same day [109].

On the fifth day immediately following the above-mentioned 4 days, the retention test was performed. The platform was removed, and the mouse was released into the center of the tank. During two $60 \mathrm{~s}$ trials separated by $15 \mathrm{~s}$ intervals, the time spent (\%) in the target quadrant was measured. Mean values of the two trials were calculated.

\subsubsection{Fluorescence Microscopy}

At least 6 weeks after AAV injection, mice were transcardially perfused for 2 min with $5 \mathrm{~mL}$ of phosphate-buffered saline (PBS) and $25 \mathrm{~mL}$ of a $4 \%$ paraformaldehyde solution for $10 \mathrm{~min}$ under anesthesia. The brain was removed and postfixed with $4 \%$ paraformaldehyde for $5 \mathrm{~h}$ and immersed in 30\% sucrose in PBS for 2 days. Sequential $20 \mu \mathrm{m}$ slices were prepared on a cryostat (Thermo Fisher Scientific Inc., Waltham, MA, USA). Cell nuclei were stained with a bis-benzimide solution (Hoechst 33258 dye, $5 \mu \mathrm{g} / \mathrm{mL}$ in PBS; Sigma-Aldrich, Burlington, MA, USA). Finally, the sections were mounted in an antiquenching medium (Fluoromount G; Southern Biotechnology Associates, Burlington, $\mathrm{NC}$, USA) followed by examination under a Zeiss AxioImager microscope with $2.5 \times$ and $20 \times$ air-immersion objectives.

\subsubsection{3. qPCR}

The frozen hippocampi were homogenized with TRIzol (Invitrogen, Waltham, MA, USA) according to the manufacturer's instructions. Total RNA was extracted, and $1 \mu \mathrm{g}$ of the total RNA was subjected to cDNA synthesis with a random hexanucleotide mixture. The numbers of copies of Cc2d1a/Freud-1, Htr1a, Maoa, Tph2, Bdnf, Ntrk2, Ngfr, Rela, Nfkb1, Creb, and cFos cDNAs were estimated by SYBR Green qPCR with specific primers (Table 1). We used 50,100, 200, 400, 800, 1600, 3200, and 6400 copies of genomic DNA as external standards for all the studied genes. The gene expression was presented as the number of cDNA copies per 100 copies of Polr2a cDNA [110-112]. 
Table 1. The primer sequences, annealing temperatures, and PCR product length.

\begin{tabular}{|c|c|c|c|}
\hline Gene & Sequence & Annealing Temperature, ${ }^{\circ} \mathrm{C}$ & Product Length, bp \\
\hline Htr1a & $\begin{array}{c}\text { F } 5^{\prime} \text {-ctgtgacctgtttatcgccctg- } 3^{\prime} \\
\text { R } 5^{\prime} \text {-gtagtctatagggtcggtgattgc- } 3^{\prime}\end{array}$ & 62 & 200 \\
\hline$C c 2 d 1 a$ & $\begin{array}{l}\text { F 5'-gcaaagccgggcaacatcatc-3' } \\
\text { R 5'-tagcagaggtgggtgtagtgg- } 3^{\prime}\end{array}$ & 60 & 181 \\
\hline$B d n f$ & $\begin{array}{l}\text { F } 5^{\prime} \text {-tagcaaaaagagaattggctg- } 3^{\prime} \\
\text { R } 5^{\prime} \text {-tttcaggtcatggatatgtcc- } 3^{\prime}\end{array}$ & 59 & 255 \\
\hline Ntrk2 & $\begin{array}{l}\text { F } 5^{\prime} \text {-cattcactgtgagaggcaacc- } 3^{\prime} \\
\text { F } 5^{\prime} \text {-atcagggtgtagtctccgttatt- } 3^{\prime}\end{array}$ & 63 & 175 \\
\hline$N g f r$ & $\begin{array}{l}\text { F } 5^{\prime} \text {-acaacacccagcacccagga- } 3^{\prime} \\
\text { R } 5^{\prime} \text {-cacaaccacagcagccaaga- } 3^{\prime}\end{array}$ & 62 & 171 \\
\hline Rela & $\begin{array}{l}\text { F } 5^{\prime} \text {-gcacctgttccaaagagcac- } 3^{\prime} \\
\text { R } 5^{\prime} \text {-gagttgtccacagatgccagg- } 3^{\prime}\end{array}$ & 64 & 93 \\
\hline$N f k b 1$ & $\begin{array}{l}\text { F } 5^{\prime} \text {-cgtctgtctgctctctctcgac- } 3^{\prime} \\
\text { R } 5^{\prime} \text {-ctcgcctcggtacttctctctc- } 3^{\prime}\end{array}$ & 64 & 152 \\
\hline Creb & $\begin{array}{l}\text { F } 5^{\prime} \text {-gctggctaacaatggtacggat- } 3^{\prime} \\
\text { R } 5^{\prime} \text {-tggttgctgggcactagaat- } 3^{\prime}\end{array}$ & 64 & 140 \\
\hline cFos & $\begin{array}{c}\mathrm{F} 5^{\prime} \text {-aaagagaaggaaaaactggag- } 3^{\prime} \\
\mathrm{R} 5^{\prime} \text {-cggaaacaagaagtcatcaa-3' }\end{array}$ & 58 & 264 \\
\hline Tph2 & $\begin{array}{c}\text { F } 5^{\prime} \text {-cattcctcgcacaattccagtcg-3' } \\
\text { R } 5^{\prime} \text {-cttgacatattcaactagacgctc- } 3^{\prime} \\
\text { F } 5^{\prime}-\end{array}$ & 61 & 239 \\
\hline Маоа & $\begin{array}{l}\text { atgaggatgttaaatgggtagatgttggt-3' } \\
\text { R } 5^{\prime} \text {-cttgacatattcaactagacgctc- }\end{array}$ & 61 & 138 \\
\hline Polr $2 a$ & $\begin{array}{l}\text { F } 5^{\prime} \text {-tgtgacaactccatacaatgc-3' } \\
\text { R 5'-ctctcttagtgaatttgcgtact- } 3^{\prime}\end{array}$ & 60 & 194 \\
\hline
\end{tabular}

\subsubsection{HPLC}

The frozen hippocampi were homogenized in the Potter-Elvehjem homogenizer in $200 \mu \mathrm{L}$ of $0.6 \mathrm{M} \mathrm{HClO} 4$ (Sigma-Aldrich, Burlington, MA, USA) containing $200 \mathrm{ng} / \mathrm{mL}$ isoproterenol (Sigma-Aldrich, Burlington, MA, USA) as an internal standard. The homogenate was centrifuged at $12,000 \times g$ for $15 \mathrm{~min}$ at $4{ }^{\circ} \mathrm{C}$ for protein precipitation. The supernatants were diluted twofold with ultra-pure water and filtered in a centrifuge tube with a $0.22 \mu \mathrm{m}$ cellulose acetate filter (Spin- $X^{\circledR}$, Burlington, MA, USA). The pellet was stored at $-20^{\circ} \mathrm{C}$ until protein quantitation by the Bradford method. Twenty microliters of the filtered supernatant was injected into the loop of the HPLC system containing the following components: an electrochemical detector $(750 \mathrm{mV}$, DECADE IITM Electrochemical Detector; Antec, The Netherlands), a glassy carbon flow cell (VT-03 cell 3 mm GC sb; Antec, The Netherlands), system controller CBM-20A, solvent delivery unit LC-20AD, auto sampler SIL-20A, and degasser DGU-20A5R (Shimadzu Corporation, Japan). Chromatographic separation of substances was carried out by isocratic elution at a flow rate of $0.6 \mathrm{~mL} / \mathrm{min}$ on a C18 column ( $5 \mu \mathrm{m}$ particle size, $\mathrm{L} \times \mathrm{I}$.D. $75 \times 4.6 \mathrm{~mm}$, Luna, Penomenex, Torrance, CA, USA) protected by a C8 security guard (Penomenex, Torrance, CA, USA) cartridge. The mobile phase was a mixture of $90 \%$ of $50 \mathrm{mM}$ phosphate buffer (Sigma-Aldrich, Burlington, MA, USA) containing $2 \%$ of octanesulfonic acid sodium salt (Chimmed, Moscow, Russia) ( $\mathrm{pH} 3.9$ ) and $10 \%$ of methanol (Chimmed, Moscow, Russia). The temperature of the column was stabilized at $40{ }^{\circ} \mathrm{C}$. The amounts (ng) of substances were calculated relative to the internal standard. The concentrations of the substances were expressed in $\mathrm{ng} / \mathrm{mg}$ of protein (as determined by the Bradford assay).

\subsubsection{Western Blot}

For assessment of total protein levels, the frozen hippocampi were homogenized in LB buffer ( $300 \mathrm{mM} \mathrm{NaCl}, 100 \mathrm{mM}$ Tris- $\mathrm{HCl} \mathrm{pH} 8.4 \mathrm{mM}$ EDTA, $0.2 \%$ of Triton X-100, $1 \mathrm{mM}$ Na3VO4, $2 \mathrm{mM}$ PMSF, and a protease inhibitor cocktail), incubated for $60 \mathrm{~min}$ on ice, and centrifuged $(12,000 \times g, 15 \mathrm{~min})$. Supernatant protein was transferred to a clean 
tube and kept at $-80{ }^{\circ} \mathrm{C}$. Protein concentration was estimated spectrophotometrically using the Pierce BCA Protein Assay Kit (Thermo Fisher Scientific Inc., Waltham, MA, USA) on NanoDrop 2000C (Thermo Fisher Scientific Inc., Waltham, MA, USA) followed by adjustment of the samples to equal concentrations of protein with $2 \times$ Laemmli sample buffer. The proteins were denatured by boiling for $10 \mathrm{~min}$ at $95{ }^{\circ} \mathrm{C}$. The protein extracts ( $30 \mu \mathrm{g}$ per lane for BDNF and proBDNF analyses and $15 \mu \mathrm{g}$ per lane for the analysis of other proteins: CC2D1A/Freud-1, 5-HT $1 \mathrm{~A}, \mathrm{MAOA}, \mathrm{TPH} 2, \mathrm{CREB}, \mathrm{pCREB}, \mathrm{p} 75^{\mathrm{NTR}}$, and TrkB) were resolved by SDS-PAGE and blotted onto a nitrocellulose membrane (Bio-Rad Laboratories, Inc., Hercules, CA, USA) in a Trans-Blot Turbo Transfer System (Bio-Rad Laboratories, Inc., Hercules, CA, USA). The membranes were blocked in Tris-buffered saline supplemented with $0.05 \%$ of Tween 20 (TBST) containing $5 \%$ of nonfat dry milk (NFDM-TBST) (for BDNF, proBDNF, CC2D1A/Freud-1, 5-HT 1A, MAOA, TPH2, p75 ${ }^{\mathrm{NTR}}$, CREB and TrkB), for pCREB the membrane was blocked in 5\% BSA. All membranes were blocked for $1 \mathrm{~h}$, rinsed, and next incubated with primary antibodies (Table 2). After protein detection (as described below), all blots were stripped and then reprobed with an antiGAPDH antibody as a loading control. For protein detection, the membranes were washed in TBST $(5 \times 5 \mathrm{~min})$, followed by incubation with a secondary antibody conjugated with horseradish peroxidase. After washing, the blots were treated with the Clarity Western ECL Substrate (Bio-Rad Laboratories, Inc., Hercules, CA, USA) according to the manufacturer's instructions. Protein bands were detected using a C-DiGit Blot Scanner (LI-COR, Lincoln, NE, USA). Quantification of protein bands was performed by means of ImageStudio (LICOR, Lincoln, NE, USA). Target protein levels were normalized to GAPDH levels and are presented as a percentage of the control animals' values.

Table 2. The list of antibodies used and immunodetection conditions.

\begin{tabular}{|c|c|c|}
\hline Antibodies, Manufacturer, Cat. No. & Dilution & Incubation Time, Conditions \\
\hline $\begin{array}{l}\text { Rabbit polyclonal antibody to } 5-\mathrm{HT}_{1 \mathrm{~A}} \\
\text { protein, Abcam, Cambridge, UK, ab85615 }\end{array}$ & $\begin{array}{c}\text { 1:1000 in TBST supplemented with } \\
5 \% \text { milk powder }\end{array}$ & Night at $4{ }^{\circ} \mathrm{C}$, as a primary antibody \\
\hline $\begin{array}{l}\text { Rabbit monoclonal antibody to } \\
\text { CC2D1A/Freud-1 protein, Abcam, } \\
\text { Cambridge, UK, ab191472 }\end{array}$ & $\begin{array}{c}\text { 1:2000 in TBST supplemented with } \\
5 \% \text { milk powder }\end{array}$ & Night at $4{ }^{\circ} \mathrm{C}$, as a primary antibody \\
\hline $\begin{array}{l}\text { Rabbit antibody to BDNF protein, Abcam, } \\
\text { Cambridge, UK, ab46176 }\end{array}$ & $\begin{array}{c}\text { 1:1000 in TBST supplemented with } \\
5 \% \text { milk powder }\end{array}$ & Night at $4{ }^{\circ} \mathrm{C}$, as a primary antibody \\
\hline $\begin{array}{l}\text { Mouse antibody to pro-BDNF protein, } \\
\text { Santa Cruz Biotechnology, Dallas, TX, } \\
\text { USA, sc65513 }\end{array}$ & $\begin{array}{c}\text { 1:250 in TBST supplemented with } \\
5 \% \text { milk powder }\end{array}$ & Night at $4{ }^{\circ} \mathrm{C}$, as a primary antibody \\
\hline $\begin{array}{c}\text { Rabbit antibody to p } 75^{\text {NTR }} \text {, Abcam, } \\
\text { Cambridge, UK, ab38335 }\end{array}$ & $\begin{array}{c}\text { 1:500 in TBST supplemented with } \\
5 \% \text { milk powder }\end{array}$ & $2 \mathrm{~h}$ at $\mathrm{RT}$, as a primary antibody \\
\hline $\begin{array}{c}\text { Rabbit antibody to TrkB, Abcam, } \\
\text { Cambridge, UK, ab18987 }\end{array}$ & $\begin{array}{c}\text { 1:400 in TBST supplemented with } \\
\text { 3\% BSA }\end{array}$ & Night at $4{ }^{\circ} \mathrm{C}$, as a primary antibody \\
\hline $\begin{array}{l}\text { Rabbit monoclonal [E113] antibody to } \\
\text { CREB protein (phospho S133), Abcam, } \\
\text { Cambridge, UK, ab32096 }\end{array}$ & $\begin{array}{c}\text { 1:1000 in TBST supplemented with } \\
5 \% \text { BSA }\end{array}$ & Night at $4{ }^{\circ} \mathrm{C}$, as a primary antibody \\
\hline $\begin{array}{l}\text { Rabbit polyclonal antibody to CREB } \\
\text { protein, Abcam, Cambridge, UK, ab31387 }\end{array}$ & $\begin{array}{c}\text { 1:1000 in TBST supplemented with } \\
5 \% \text { BSA }\end{array}$ & Night at $4{ }^{\circ} \mathrm{C}$, as a primary antibody \\
\hline $\begin{array}{l}\text { Rabbit polyclonal antibody to GAPDH } \\
\text { protein, Abcam, Cambridge, UK, ab9485 }\end{array}$ & $\begin{array}{c}\text { 1:2500 in TBST supplemented } \\
\text { with } 5 \% \text { BSA }\end{array}$ & Night at $4^{\circ} \mathrm{C}$, as a primary antibody \\
\hline $\begin{array}{l}\text { Rabbit polyclonal antibody to MAOA } \\
\text { Abcam, Cambridge, UK, ab126751 }\end{array}$ & $\begin{array}{c}\text { 1:500 in TBST supplemented with } \\
5 \% \text { milk powder }\end{array}$ & Night at $4^{\circ} \mathrm{C}$, as a primary antibody \\
\hline $\begin{array}{l}\text { Rabbit polyclonal antibody to TPH2 } \\
\text { Abcam, Cambridge, UK, ab184505 }\end{array}$ & $\begin{array}{c}\text { 1:1000 in TBST supplemented with } \\
5 \% \text { milk powder }\end{array}$ & Night at $4{ }^{\circ} \mathrm{C}$, as a primary antibody \\
\hline $\begin{array}{c}\text { Goat anti-rabbit IgG antibody conjugated } \\
\text { to horseradish peroxidase, Invitrogen, } \\
\text { Waltham, MA, USA, G-21234 }\end{array}$ & $\begin{array}{c}\text { 1:10000 in TBST supplemented with } \\
5 \% \text { milk powder }\end{array}$ & $1 \mathrm{~h}$ at $\mathrm{RT}$, as a secondary antibody \\
\hline $\begin{array}{l}\text { Goat anti-mouse IgG antibody } \\
\text { conjugated to horseradish peroxidase, } \\
\text { Abcam, Cambridge, UK, ab6728 }\end{array}$ & $\begin{array}{c}\text { 1:2000 in TBST supplemented with } \\
5 \% \text { milk powder }\end{array}$ & $1 \mathrm{~h}$ at $\mathrm{RT}$, as a secondary antibody \\
\hline
\end{tabular}




\subsubsection{Statistical Analysis}

All values are presented as means \pm SEM. Differences were assessed by one-way ANOVA and two-way ANOVA for repeated measures (Morris water maze test) followed by Fisher's post hoc test. Statistical significance was set to $p<0.05$. The normality of variances was examined by the Kolmogorov-Smirnov and Shapiro-Wilk tests. For all variances, statistical significance in both tests was assumed at $p>0.05$, which indicates a normal distribution. The Dixon test was conducted to identify and exclude outliers from the analysis; for relative values, outlier removal from a dataset was performed for the absolute values. The time spent in the quadrants in the retention test was compared with the chance level (25\%) by two-tailed Student's $t$ test for a single sample.

\section{Conclusions}

This study shows for the first time that a knockdown of Cc2d1a/Freud-1 in the hippocampus impairs spatiotemporalmemory and exerts an antidepressant action accompanied by significant changes in both the brain 5-HT system and BDNF. Meanwhile, the Cc2d1a/Freud-1 knockdown reduces 5- $\mathrm{HT}_{1 \mathrm{~A}}$ receptor functional activity and raises 5 HT and 5-HIAA levels in the hippocampus of C57BL6/J mice. Our data suggest that $\mathrm{BDNF}$ and transcription factor CREB are also involved in the mechanism underlying the CC2D1A/Freud-1-dependent antidepressant effect. Moreover, CC2D1A/Freud-1 can affect BDNF function thereby possibly playing a substantial part in the pathogenesis of various mental disorders, including depression.

Author Contributions: Conceptualization, E.M.K. and V.S.N.; methodology, T.V.I., D.V.E., A.Y.R., A.V.P. and V.S.N.; validation, E.M.K.; formal analysis, E.M.K., A.Y.R. and A.V.P.; investigation, E.M.K., D.V.E., A.Y.R., A.V.P., Y.D.G., V.S.N.; resources E.M.K., data curation, E.M.K. and V.S.N.; writingoriginal draft preparation, E.M.K., T.V.I., A.V.P. and V.S.N.; writing-review and editing, E.M.K. and V.S.N.; visualization, T.V.I.; supervision, V.S.N.; project administration, E.M.K.; funding acquisition, E.M.K. All authors have read and agreed to the published version of the manuscript.

Funding: This study was supported by the Russian Science Foundation, grant No. 19-15-00027.

Institutional Review Board Statement: All experimental procedures were carried out in compliance with the Guide for the Care and Use of Laboratory Animals approved by the Ministry of Public Health of Russia (supplement to order N 267, 19 June 2003) and were approved by the ethical committee of the Institute of Cytology and Genetics (protocol No. 33, 15 June 2016).

Informed Consent Statement: Not applicable.

Data Availability Statement: The datasets generated during the current study are available from the corresponding author on reasonable request.

Acknowledgments: Microscopy was performed at the Microscopy Center of the ICG SB RAS, Russia.

Conflicts of Interest: Authors declare no conflict of interest.

\section{References}

1. Harro, J.; Oreland, L. Depression as a spreading neuronal adjustment disorder. Eur. Neuropsychopharmacol. 1996, 6, 207-223. [CrossRef]

2. Duman, R.S.; Heninger, G.R.; Nestler, E.J. A Molecular and Cellular Theory of Depression. Arch. Gen. Psychiatry 1997, 54, 597-606. [CrossRef]

3. Jans, L.A.W.; Riedel, W.J.; Markus, C.R.; Blokland, A. Serotonergic vulnerability and depression: Assumptions, experimental evidence and implications. Mol. Psychiatry 2006, 12, 522-543. [CrossRef]

4. Popova, N.K.; Naumenko, V.S. 5-HT1A receptor as a key player in the brain 5-HT system. Rev. Neurosci. 2013, 24, 1-14. [CrossRef]

5. Barnes, N.M.; Sharp, T. A review of central 5-HT receptors and their function. Neuropharmacology 1999, 38, 1083-1152. [CrossRef]

6. Albert, P.R.; Le François, B.; Millar, A.M. Transcriptional dysregulation of 5-HT1A autoreceptors in mental illness. Mol. Brain 2011, 4, 21. [CrossRef]

7. Fuller, R.W. Role of serotonin in therapy of depression and related disorders. J. Clin. Psychiatry 1991, 52, 52-57. [PubMed]

8. Heisler, L.K.; Chu, H.-M.; Brennan, T.J.; Danao, J.A.; Bajwa, P.; Parsons, L.H.; Tecott, L.H. Elevated anxiety and antidepressant-like responses in serotonin 5-HT1A receptor mutant mice. Proc. Natl. Acad. Sci. USA 1998, 95, 15049-15054. [CrossRef] [PubMed] 
9. Overstreet, D.H.; Commissaris, R.C.; De La Garza, R., 2nd; File, S.E.; Knapp, D.J.; Seiden, L.S. Involvement of 5-HT1A receptors in animal tests of anxiety and depression: Evidence from genetic models. Stress 2003, 6, 101-110. [CrossRef] [PubMed]

10. Ramboz, S.; Oosting, R.; Amara, D.A.; Kung, H.F.; Blier, P.; Mendelsohn, M.; Mann, J.J.; Brunner, D.; Hen, R. Serotonin receptor 1A knockout: An animal model of anxiety-related disorder. Proc. Natl. Acad. Sci. USA 1998, 95, 14476-14481. [CrossRef]

11. Richardson-Jones, J.W.; Craige, C.P.; Guiard, B.P.; Stephen, A.; Metzger, K.L.; Kung, H.F.; Gardier, A.M.; Dranovsky, A.; David, D.; Beck, S.G.; et al. 5-HT1A Autoreceptor Levels Determine Vulnerability to Stress and Response to Antidepressants. Neuron 2010, 65, 40-52. [CrossRef] [PubMed]

12. Maes, M.; Meltzer, H.Y. The serotonin hypothesis of major depression. In Psychopharmacology: The Fourth Generation of Progress; Bloom, E.E., Kupfer, N.N., Eds.; Raven Press: New York, NY, USA, 1995; pp. 933-944.

13. Arango, V.; Huang, Y.-Y.; Underwood, M.; Mann, J. Genetics of the serotonergic system in suicidal behavior. J. Psychiatr. Res. 2003, 37, 375-386. [CrossRef]

14. Stockmeier, C.A.; Shapiro, L.A.; Dilley, G.E.; Kolli, T.N.; Friedman, L.; Rajkowska, G. Increase in Serotonin-1A Autoreceptors in the Midbrain of Suicide Victims with Major Depression-Postmortem Evidence for Decreased Serotonin Activity. J. Neurosci. 1998, 18, 7394-7401. [CrossRef]

15. Lowther, S.; De Paermentier, F.; Cheetham, S.C.; Crompton, M.; Katona, C.L.; Horton, R.W. 5-HT1A Receptor binding sites in post-mortem brain samples from depressed suicides and controls. J. Affect. Disord. 1997, 42, 199-207. [CrossRef]

16. Albert, P.; Lemonde, S. 5-HT1A Receptors, Gene Repression, and Depression: Guilt by Association. Neuroscientist 2004, 10, 575-593. [CrossRef]

17. Shively, C.A.; Friedman, D.P.; Gage, H.D.; Bounds, M.C.; Brown-Proctor, C.; Blair, J.B.; Henderson, J.A.; Smith, M.A.; Buchheimer, N. Behavioral Depression and Positron Emission Tomography-Determined Serotonin 1A Receptor Binding Potential in Cynomolgus Monkeys. Arch. Gen. Psychiatry 2006, 63, 396-403. [CrossRef]

18. Sargent, P.A.; Kjaer, K.H.; Bench, C.J.; Rabiner, E.A.; Messa, C.; Meyer, J.; Gunn, R.N.; Grasby, P.M.; Cowen, P.J. Brain serotonin1A receptor binding measured by positron emission tomography with [11C]WAY-100635: Effects of depression and antidepressant treatment. Arch. Gen. Psychiatry 2000, 57, 174-180. [CrossRef]

19. Bhagwagar, Z.; Rabiner, E.A.; Sargent, P.A.; Grasby, P.M.; Cowen, P.J. Persistent reduction in brain serotonin1A receptor binding in recovered depressed men measured by positron emission tomography with [11C]WAY-100635. Mol. Psychiatry 2004, 9, 386-392. [CrossRef] [PubMed]

20. Moses-Kolko, E.L.; Wisner, K.; Price, J.C.; Berga, S.L.; Drevets, W.C.; Hanusa, B.H.; Loucks, T.; Meltzer, C.C. Serotonin 1A receptor reductions in postpartum depression: A positron emission tomography study. Fertil. Steril. 2008, 89, 685-692. [CrossRef]

21. Stockmeier, C.A.; Howley, E.; Shi, X.; Sobanska, A.; Clarke, G.; Friedman, L.; Rajkowska, G. Antagonist but not agonist labeling of serotonin-1A receptors is decreased in major depressive disorder. J. Psychiatr. Res. 2009, 43, 887-894. [CrossRef] [PubMed]

22. Neumeister, A.; Bain, E.; Nugent, A.C.; Carson, R.E.; Bonne, O.; Luckenbaugh, D.A.; Eckelman, W.; Herscovitch, P.; Charney, D.S.; Drevets, W.C. Reduced serotonin type 1A receptor binding in panic disorder. J. Neurosci. 2004, 24, 589-591. [CrossRef]

23. Sullivan, G.M.; Oquendo, M.A.; Simpson, N.; Van Heertum, R.L.; Mann, J.J.; Parsey, R.V. Brain Serotonin1A Receptor Binding in Major Depression Is Related to Psychic and Somatic Anxiety. Biol. Psychiatry 2005, 58, 947-954. [CrossRef]

24. Lanzenberger, R.R.; Mitterhauser, M.; Spindelegger, C.; Wadsak, W.; Klein, N.; Mien, L.-K.; Holik, A.; Attarbaschi, T.; Mossaheb, N.; Sacher, J.; et al. Reduced Serotonin-1A Receptor Binding in Social Anxiety Disorder. Biol. Psychiatry 2007, 61, 1081-1089. [CrossRef] [PubMed]

25. Drevets, W.C.; Thase, M.E.; Moses-Kolko, E.L.; Price, J.; Frank, E.; Kupfer, D.J.; Mathis, C. Serotonin-1A receptor imaging in recurrent depression: Replication and literature review. Nucl. Med. Biol. 2007, 34, 865-877. [CrossRef]

26. Boldrini, M.; Underwood, M.; Mann, J.J.; Arango, V. Serotonin-1A autoreceptor binding in the dorsal raphe nucleus of depressed suicides. J. Psychiatr. Res. 2008, 42, 433-442. [CrossRef] [PubMed]

27. Ou, X.-M.; Jafar-Nejad, H.; Storring, J.M.; Meng, J.-H.; Lemonde, S.; Albert, P. Novel Dual Repressor Elements for Neuronal Cell-specific Transcription of the Rat 5-HT1A Receptor Gene. J. Biol. Chem. 2000, 275, 8161-8168. [CrossRef]

28. Ou, X.-M.; Lemonde, S.; Jafar-Nejad, H.; Bown, C.D.; Goto, A.; Rogaeva, A.; Albert, P.R. Freud-1: A Neuronal Calcium-Regulated Repressor of the 5-HT1A Receptor Gene. J. Neurosci. 2003, 23, 7415-7425. [CrossRef]

29. Zhao, M.; Raingo, J.; Chen, Z.J.; Kavalali, E.T. Cc2d1a, a C2 domain containing protein linked to nonsyndromic mental retardation, controls functional maturation of central synapses. J. Neurophysiol. 2011, 105, 1506-1515. [CrossRef]

30. Al-Tawashi, A.; Jung, S.Y.; Liu, D.; Su, B.; Qin, J. Protein Implicated in Nonsyndromic Mental Retardation Regulates Protein Kinase A (PKA) Activity. J. Biol. Chem. 2012, 287, 14644-14658. [CrossRef]

31. Chen, K.R.; Chang, C.H.; Huang, C.Y.; Lin, C.Y.; Lin, W.Y.; Lo, Y.C.; Yang, C.Y.; Hsing, E.W.; Chen, L.F.; Shih, S.R.; et al. TBK1-associated protein in endolysosomes (TAPE)/CC2D1A is a key regulator linking RIG-I-like receptors to antiviral immunity. J. Biol. Chem. 2012, 287, 32216-32221. [CrossRef] [PubMed]

32. Vahid-Ansari, F.; Daigle, M.; Manzini, M.C.; Tanaka, K.F.; Hen, R.; Geddes, S.D.; Beique, J.C.; James, J.; Merali, Z.; Albert, P.R. Abrogated Freud-1/Cc2d1a Repression of 5-HT1A Autoreceptors Induces Fluoxetine-Resistant Anxiety/Depression-Like Behavior. J. Neurosci. 2017, 37, 11967-11978. [CrossRef]

33. Albert, P.; Lembo, P.; Storring, J.M.; Charest, A.; Saucier, C. The 5-HT1A receptor: Signaling, desensitization, and gene transcription. Neuropsychopharmacology 1996, 14, 19-25. [CrossRef] 
34. Albert, P.R.; Francois, B.L. Modifying 5-HT1A Receptor Gene Expression as a New Target for Antidepressant Therapy. Front. Neurosci. 2010, 4, 35. [CrossRef] [PubMed]

35. Castrén, E.; Rantamäki, T. The role of BDNF and its receptors in depression and antidepressant drug action: Reactivation of developmental plasticity. Dev. Neurobiol. 2010, 70, 289-297. [CrossRef]

36. Sun, L.-J.; Zhang, L.-M.; Liu, D.; Xue, R.; Liu, Y.-Q.; Li, L.; Guo, Y.; Shang, C.; Yao, J.-Q.; Zhang, Y.-Z.; et al. The faster-onset antidepressant effects of hypidone hydrochloride (YL-0919). Metab. Brain Dis. 2019, 34, 1375-1384. [CrossRef]

37. Lu, B.; Pang, P.T.; Woo, N.H. The yin and yang of neurotrophin action. Nat. Rev. Neurosci. 2005, 6, 603-614. [CrossRef] [PubMed]

38. Benarroch, E.E. Brain-derived neurotrophic factor: Regulation, effects, and potential clinical relevance. Neurology 2015, 84, 1693-1704. [CrossRef]

39. Kenchappa, R.S.; Tep, C.; Korade, Z.; Urra, S.; Bronfman, F.C.; Yoon, S.O.; Carter, B.D. p75 Neurotrophin Receptor-mediated Apoptosis in Sympathetic Neurons Involves a Biphasic Activation of JNK and Up-regulation of Tumor Necrosis Factor- $\alpha$ converting Enzyme/ADAM17. J. Biol. Chem. 2010, 285, 20358-20368. [CrossRef]

40. Deinhardt, K.; Chao, M. Shaping neurons: Long and short range effects of mature and proBDNF signalling upon neuronal structure. Neuropharmacology 2014, 76, 603-609. [CrossRef]

41. Popova, N.K.; Ilchibaeva, T.V.; Naumenko, V.S. Neurotrophic factors (BDNF and GDNF) and the serotonergic system of the brain. Biochemistry 2017, 82, 308-317. [CrossRef] [PubMed]

42. Popova, N.K.; Naumenko, V.S. Neuronal and behavioral plasticity: The role of serotonin and BDNF systems tandem. Expert Opin. Ther. Targets 2019, 23, 227-239. [CrossRef]

43. Oeckinghaus, A.; Ghosh, S. The NF-kappaB family of transcription factors and its regulation. Cold Spring Harb. Perspect. Biol. 2009, 1, a000034. [CrossRef]

44. Zamarbide, M.; Mossa, A.; Muñoz-Llancao, P.; Wilkinson, M.K.; Pond, H.L.; Oaks, A.W.; Manzini, M.C. Male-Specific cAMP Signaling in the Hippocampus Controls Spatial Memory Deficits in a Mouse Model of Autism and Intellectual Disability. Biol. Psychiatry 2019, 85, 760-768. [CrossRef] [PubMed]

45. Kraemer, B.R.; Yoon, S.O.; Carter, B.D. The Biological Functions and Signaling Mechanisms of the p75 Neurotrophin Receptor. Mediat. Drugs Gastrointest. Motil. I 2014, 220, 121-164.

46. Wissink, S.; Meijer, O.; Pearce, D.; van der Burg, B.; van der Saag, P.T. Regulation of the Rat Serotonin-1A Receptor Gene by Corticosteroids. J. Biol. Chem. 2000, 275, 1321-1326. [CrossRef]

47. Ying, S.-W.; Futter, M.; Rosenblum, K.; Webber, M.J.; Hunt, S.; Bliss, T.V.P.; Bramham, C. Brain-Derived Neurotrophic Factor Induces Long-Term Potentiation in Intact Adult Hippocampus: Requirement for ERK Activation Coupled to CREB and Upregulation ofArcSynthesis. J. Neurosci. 2002, 22, 1532-1540. [CrossRef]

48. Overstreet, D.H. Modeling Depression in Animal Models. Psychiatr. Disord. 2012, 829, 125-144.

49. Khotskin, N.V.; Plyusnina, A.V.; Kulikova, E.A.; Bazhenova, E.Y.; Fursenko, D.V.; Sorokin, I.E.; Kolotygin, I.; Mormede, P.; Terenina, E.E.; Shevelev, O.B.; et al. On association of the lethal yellow $(\mathrm{A}(\mathrm{Y}))$ mutation in the agouti gene with the alterations in mouse brain and behavior. Behav. Brain Res. 2019, 359, 446-456. [CrossRef]

50. Santarelli, L.; Saxe, M.; Gross, C.; Surget, A.; Battaglia, F.; Dulawa, S.; Weisstaub, N.; Lee, J.; Duman, R.; Arancio, O.; et al. Requirement of Hippocampal Neurogenesis for the Behavioral Effects of Antidepressants. Science 2003, 301, 805-809. [CrossRef]

51. Porsolt, R.D.; Bertin, A.; Jalfre, M. "Behavioural despair" in rats and mice: Strain differences and the effects of imipramine. Eur. J. Pharmacol. 1978, 51, 291-294. [CrossRef]

52. Oaks, A.W.; Zamarbide, M.; Tambunan, D.E.; Santini, E.; Di Costanzo, S.; Pond, H.L.; Johnson, M.W.; Lin, J.; Gonzalez, D.; Boehler, J.F.; et al. Cc2d1a Loss of Function Disrupts Functional and Morphological Development in Forebrain Neurons Leading to Cognitive and Social Deficits. Cereb. Cortex 2017, 27, 1670-1685. [CrossRef]

53. Yang, C.-Y.; Yu, T.-H.; Wen, W.-L.; Ling, P.; Hsu, K.-S. Conditional Deletion of CC2D1A Reduces Hippocampal Synaptic Plasticity and Impairs Cognitive Function through Rac1 Hyperactivation. J. Neurosci. 2019, 39, 4959-4975. [CrossRef]

54. Fanselow, M.S.; Dong, H.-W. Are the Dorsal and Ventral Hippocampus Functionally Distinct Structures? Neuron 2010, 65, 7-19. [CrossRef] [PubMed]

55. Pothuizen, H.H.J.; Zhang, W.-N.; Jongen-Relo, A.L.; Feldon, J.; Yee, B.K. Dissociation of function between the dorsal and the ventral hippocampus in spatial learning abilities of the rat: A within-subject, within-task comparison of reference and working spatial memory. Eur. J. Neurosci. 2004, 19, 705-712. [CrossRef]

56. Kheirbek, M.; Drew, L.J.; Burghardt, N.S.; Costantini, D.O.; Tannenholz, L.; Ahmari, S.E.; Zeng, H.; Fenton, A.; Hen, R. Differential Control of Learning and Anxiety along the Dorsoventral Axis of the Dentate Gyrus. Neuron 2013, 77, 955-968. [CrossRef] [PubMed]

57. Sanger, D.J.; Joly, D. Performance of a passive avoidance response is disrupted by compounds acting at 5HT(1A) receptors. Behav. Pharmacol. 1989, 1, 235-240.

58. Carli, M.; Samanin, R. 8-Hydroxy-2-(di-n-propylamino)tetralin impairs spatial learning in a water maze: Role of postsynaptic 5-HT1A receptors. Br. J. Pharmacol. 1992, 105, 720-726. [CrossRef]

59. Luttgen, M.; Elvander, E.; Madjid, N.; Ogren, S.O. Analysis of the role of 5-HT1A receptors in spatial and aversive learning in the rat. Neuropharmacology 2005, 48, 830-852. [CrossRef]

60. Carli, M.; Lazarova, M.; Tatarczynska, E.; Samanin, R. Stimulation of 5-HT1A receptors in the dorsal hippocampus impairs acquisition and performance of a spatial task in a water maze. Brain Res. 1992, 595, 50-56. [CrossRef] 
61. Carli, M.; Silva, S.; Balducci, C.; Samanin, R. WAY 100635, a 5-HT1A receptor antagonist, prevents the impairment of spatial learning caused by blockade of hippocampal NMDA receptors. Neuropharmacology 1999, 38, 1165-1173. [CrossRef]

62. Ögren, S.O.; Eriksson, T.M.; Elvander-Tottie, E.; D'Addario, C.; Ekström, J.C.; Svenningsson, P.; Meister, B.; Kehr, J.; Stiedl, O. The role of 5-HT1A receptors in learning and memory. Behav. Brain Res. 2008, 195, 54-77. [CrossRef]

63. Bianchi, M.; Moser, C.; Lazzarini, C.; Vecchiato, E.; Crespi, F. Forced swimming test and fluoxetine treatment: In vivo evidence that peripheral 5-HT in rat platelet-rich plasma mirrors cerebral extracellular 5-HT levels, whilst 5-HT in isolated platelets mirrors neuronal 5-HT changes. Exp. Brain Res. 2002, 143, 191-197. [CrossRef]

64. Caccia, S.; Anelli, M.; Codegoni, A.M.; Fracasso, C.; Garattini, S. The effects of single and repeated anorectic doses of 5hydroxytryptamine uptake inhibitors on indole levels in rat brain. Br. J. Pharmacol. 1993, 110, 355-359. [CrossRef]

65. Popa, D.; Cerdan, J.; Repérant, C.; Guiard, B.P.; Guilloux, J.-P.; David, D.; Gardier, A.M. A longitudinal study of 5-HT outflow during chronic fluoxetine treatment using a new technique of chronic microdialysis in a highly emotional mouse strain. Eur. J. Pharmacol. 2010, 628, 83-90. [CrossRef]

66. Vaswani, M.; Linda, F.K.; Ramesh, S. Role of selective serotonin reuptake inhibitors in psychiatric disorders: A comprehensive review. Prog. Neuro-Psychopharmacol. Biol. Psychiatry 2003, 27, 85-102. [CrossRef]

67. Blier, P.; Seletti, B.; Gilbert, F.; Young, S.N.; Benkelfat, C. Serotonin 1A Receptor Activation and Hypothermia in Humans Lack of Evidence for a Presynaptic Mediation. Neuropsychopharmacology 2002, 27, 301-308. [CrossRef]

68. Wang, L.-E.; Zhang, X.-Q.; Yin, Y.-Q.; Zhang, Y.-H. Augmentative effect of spinosin on pentobarbital-induced loss of righting reflex in mice associated with presynaptic 5-HT1A receptor. J. Pharm. Pharmacol. 2012, 64, 277-282. [CrossRef] [PubMed]

69. Lifschytz, T.; Zozulinsky, P.; Eitan, R.; Landshut, G.; Ohayon, S.; Lerer, B. Effect of Triiodothyronine on Antidepressant Screening Tests in Mice and on Presynaptic 5-HT1A Receptors: Mediation by Thyroid Hormone $\alpha$ Receptors. J. Pharmacol. Exp. Ther. 2011, 337, 494-502. [CrossRef]

70. Overstreet, D.H.; Daws, L.C.; Schiller, G.D.; Orbach, J.; Janowsky, D.S. Cholinergic/serotonergic interactions in hypothermia: Implications for rat models of depression. Pharmacol. Biochem. Behav. 1998, 59, 777-785. [CrossRef]

71. Overstreet, D.H.; Rezvani, A.H.; Knapp, D.J.; Crews, F.T.; Janowsky, D.S. Further selection of rat lines differing in 5-HT-1A receptor sensitivity: Behavioral and functional correlates. Psychiatr. Genet. 1996, 6, 107-117. [CrossRef]

72. File, S.E.; Ouagazzal, A.-M.; Gonzalez, L.E.; Overstreet, D.H. Chronic Fluoxetine in Tests of Anxiety in Rat Lines Selectively Bred for Differential 5-HT1A Receptor Function. Pharmacol. Biochem. Behav. 1999, 62, 695-701. [CrossRef]

73. Gonzalez, L.E.; File, S.E.; Overstreet, D.H. Selectively Bred Lines of Rats Differ in Social Interaction and Hippocampal 5-HT1A Receptor Function: A Link Between Anxiety and Depression? Pharmacol. Biochem. Behav. 1998, 59, 787-792. [CrossRef]

74. Hensler, J.G.; Kovachich, G.B.; Frazer, A. A quantitative autoradiographic study of serotonin1A receptor regulation. Effect of 5,7-dihydroxytryptamine and antidepressant treatments. Neuropsychopharmacology 1991, 4, 131-144.

75. Kelly, J.; Leonard, B. The effect of tianeptine and sertraline in three animal models of depression. Neuropharmacology 1994, 33, 1011-1016. [CrossRef]

76. Riad, M.; Rbah, L.; Verdurand, M.; Aznavour, N.; Zimmer, L.; Descarries, L. Unchanged density of 5-HT1A autoreceptors on the plasma membrane of nucleus raphe dorsalis neurons in rats chronically treated with fluoxetine. Neuroscience 2008, 151, 692-700. [CrossRef]

77. Gorinski, N.; Bijata, M.; Prasad, S.; Wirth, A.; Galil, D.A.; Zeug, A.; Bazovkina, D.; Kondaurova, E.; Kulikova, E.; Ilchibaeva, T.; et al. Attenuated palmitoylation of serotonin receptor 5-HT1A affects receptor function and contributes to depression-like behaviors. Nat. Commun. 2019, 10, 1-14. [CrossRef] [PubMed]

78. Naumenko, V.S.; Bazovkina, D.V.; Kondaurova, E.M. On the Functional Cross-Talk between Brain 5-HT1A and 5-HT2A Receptors. Zhurnal Vyss. Nervn. deiatelnosti Im. IP Pavlov. 2015, 65, 240-247.

79. Naumenko, V.S.; Bazovkina, D.V.; Kondaurova, E.M.; Zubkov, E.A.; Kulikov, A.V. The role of 5-HT2A receptor and 5-HT2A/5HT1A receptor interaction in the suppression of catalepsy. Genes Brain Behav. 2010, 9, 519-524.

80. Naumenko, V.S.; Popova, N.K.; Lacivita, E.; Leopoldo, M.; Ponimaskin, E.G. Interplay between Serotonin 5-HT1Aand 5HT7Receptors in Depressive Disorders. CNS Neurosci. Ther. 2014, 20, 582-590. [CrossRef]

81. Liang, T.; Chen, Q.; Li, Q.; Li, R.; Tang, J.; Hu, R.; Zhong, J.; Ge, H.; Liu, X.; Feng, H. 5-HT1a activation in PO/AH area induces therapeutic hypothermia in a rat model of intracerebral hemorrhage. Oncotarget 2017, 8, 73613-73626. [CrossRef] [PubMed]

82. Nibuya, M.; Morinobu, S.; Duman, R.S. Regulation of BDNF and trkB mRNA in rat brain by chronic electroconvulsive seizure and antidepressant drug treatments. J. Neurosci. 1995, 15, 7539-7547. [CrossRef]

83. Itoh, T.; Tokumura, M.; Abe, K. Effects of rolipram, a phosphodiesterase 4 inhibitor, in combination with imipramine on depressive behavior, CRE-binding activity and BDNF level in learned helplessness rats. Eur. J. Pharmacol. 2004, 498, 135-142. [CrossRef] [PubMed]

84. Rogóz, Z.; Legutko, B. Combined treatment with imipramine and metyrapone induces hippocampal and cortical brain-derived neurotrophic factor gene expression in rats. Pharmacol. Rep. 2005, 57, 840-844. [PubMed]

85. Brunoni, A.R.; Lopes, M.; Fregni, F. A systematic review and meta-analysis of clinical studies on major depression and BDNF levels: Implications for the role of neuroplasticity in depression. Int. J. Neuropsychopharmacol. 2008, 11, 1169-1180. [CrossRef]

86. Hellweg, R.; Ziegenhorn, A.; Heuser, I.; Deuschle, M. Serum Concentrations of Nerve Growth Factor and Brain-Derived Neurotrophic Factor in Depressed Patients before and after Antidepressant Treatment. Pharmacopsychiatry 2008, 41, 66-71. [CrossRef] [PubMed] 
87. Lee, H.-Y.; Kim, Y.-K. Plasma Brain-Derived Neurotrophic Factor as a Peripheral Marker for the Action Mechanism of Antidepressants. Neuropsychobiology 2008, 57, 194-199. [CrossRef] [PubMed]

88. Sen, S.; Duman, R.; Sanacora, G. Serum Brain-Derived Neurotrophic Factor, Depression, and Antidepressant Medications: Meta-Analyses and Implications. Biol. Psychiatry 2008, 64, 527-532. [CrossRef]

89. Changelian, P.S.; Feng, P.; King, T.C.; Milbrandt, J. Structure of the NGFI-A gene and detection of upstream sequences responsible for its transcriptional induction by nerve growth factor. Proc. Natl. Acad. Sci. USA 1989, 86, 377-381. [CrossRef] [PubMed]

90. Pinnock, S.B.; Blake, A.M.; Platt, N.J.; Herbert, J. The Roles of BDNF, pCREB and Wnt3a in the Latent Period Preceding Activation of Progenitor Cell Mitosis in The Adult Dentate Gyrus by Fluoxetine. PLoS ONE 2010, 5, e13652. [CrossRef]

91. Bourtchuladze, R.; Frenguelli, B.; Blendy, J.; Cioffi, D.; Schutz, G.; Silva, A.J. Deficient long-term memory in mice with a targeted mutation of the cAMP-responsive element-binding protein. Cell 1994, 79, 59-68. [CrossRef]

92. Okuno, H. Regulation and function of immediate-early genes in the brain: Beyond neuronal activity markers. Neurosci. Res. 2011, 69, 175-186. [CrossRef]

93. Rioja, J.; Santin, L.J.; Doña, A.; De Pablos, L.; Minano, F.J.; González-Barón, S.; Aguirre, J.A.; Sánchez, J.M. 5-HT1A receptor activation counteracts c-Fos immunoreactivity induced in serotonin neurons of the raphe nuclei after immobilization stress in the male rat. Neurosci. Lett. 2006, 397, 190-195. [CrossRef]

94. Nakamura, A.; Naito, M.; Tsuruo, T.; Fujita, N. Freud-1/Aki1, a novel PDK1-interacting protein, functions as a scaffold to activate the PDK1/Akt pathway in epidermal growth factor signaling. Mol. Cell. Biol. 2008, 28, 5996-6009. [CrossRef]

95. Chang, C.-H.; Lai, L.-C.; Cheng, H.-C.; Chen, K.-R.; Syue, Y.-Z.; Lu, H.-C.; Lin, W.-Y.; Chen, S.-H.; Huang, H.-S.; Shiau, A.-L.; et al. TBK1-associated Protein in Endolysosomes (TAPE) Is an Innate Immune Regulator Modulating the TLR3 and TLR4 Signaling Pathways. J. Biol. Chem. 2011, 286, 7043-7051. [CrossRef] [PubMed]

96. Zhao, M.; Li, X.D.; Chen, Z. CC2D1A, a DM14 and C2 domain protein, activates NF-kappaB through the canonical pathway. J. Biol. Chem. 2010, 285, 24372-24380. [CrossRef]

97. Hsiung, S.C.; Tamir, H.; Franke, T.F.; Liu, K.P. Roles of extracellular signal-regulated kinase and Akt signaling in coordinating nuclear transcription factor-kappaB-dependent cell survival after serotonin 1A receptor activation. J. Neurochem. 2005, 95, 1653-1666. [CrossRef]

98. Manzini, M.C.; Xiong, L.; Shaheen, R.; Tambunan, D.E.; Di Costanzo, S.; Mitisalis, V.; Tischfield, D.J.; Cinquino, A.; Ghaziuddin, M.; Christian, M.; et al. CC2D1A regulates human intellectual and social function as well as NF-kappaB signaling homeostasis. Cell Rep. 2014, 8, 647-655. [CrossRef] [PubMed]

99. Popova, N.K.; Naumenko, E.V. Dominance relations and the pituitary-adrenal system in rats. Anim. Behav. 1972, $20,108-111$. [CrossRef]

100. Serova, L.I.; Naumenko, E.V. The brain catecholamine systems in the regulation of dominance. Zhurnal Vyss. Nervn. Deiatelnosti Im. IP Pavlov. 1990, 40, 490-496.

101. Wirth, A.; Chen-Wacker, C.; Wu, Y.-W.; Gorinski, N.; Filippov, M.A.; Pandey, G.; Ponimaskin, E. Dual lipidation of the brainspecific Cdc42 isoform regulates its functional properties. Biochem. J. 2013, 456, 311-322. [CrossRef]

102. Grimm, D.; Kay, M.A.; Kleinschmidt, J.A. Helper virus-free, optically controllable, and two-plasmid-based production of adeno-associated virus vectors of serotypes 1 to 6. Mol. Ther. 2003, 7, 839-850. [CrossRef]

103. Kobe, F.; Guseva, P.D.; Jensen, T.; Wirth, A.; Renner, U.; Hess, D.; Müller, M.; Medrihan, L.; Zhang, W.; Zhang, M.; et al. 5-HT7R/G12 Signaling Regulates Neuronal Morphology and Function in an Age-Dependent Manner. J. Neurosci. 2012, 32, 2915-2930. [CrossRef]

104. Slotnick, B.M.; Leonard, C.M. A Stereotaxic Atlas of the Albino Mouse Forebrain; U.S. Department of Health, Education and Welfare: Rockville, MD, USA, 1975; p. 174.

105. Kulikov, A.V.; Tikhonova, M.A.; Kulikov, V.A. Automated measurement of spatial preference in the open field test with transmitted lighting. J. Neurosci. Methods 2008, 170, 345-351. [CrossRef]

106. Kulikov, A.V.; Morozova, M.V.; Kulikov, V.A.; Kirichuk, V.S.; Popova, N.K. Automated analysis of antidepressants' effect in the forced swim test. J. Neurosci. Methods 2010, 191, 26-31. [CrossRef] [PubMed]

107. Naumenko, V.S.; Kondaurova, E.; Popova, N.K. On the role of brain 5-HT7 receptor in the mechanism of hypothermia: Comparison with hypothermia mediated via 5-HT1A and 5-HT3 receptor. Neuropharmacology 2011, 61, 1360-1365. [CrossRef]

108. Kulikov, A.V.; Fursenko, D.V.; Khotskin, N.V.; Bazovkina, D.V.; Kulikov, V.A.; Naumenko, V.S.; Bazhenova, E.Y.; Popova, N.K. Spatial learning in the Morris water maze in mice genetically different in the predisposition to catalepsy: The effect of intraventricular treatment with brain-derived neurotrophic factor. Pharmacol. Biochem. Behav. 2014, 122, 266-272. [CrossRef]

109. Dalm, S.; Grootendorst, J.; De Kloet, E.R.; Oitzl, M.S. Quantification of swim patterns in the morris water maze. Behav. Res. Methods Instrum. Comput. 2000, 32, 134-139. [CrossRef] [PubMed]

110. Kulikov, A.V.; Naumenko, V.S.; Voronova, I.P.; Tikhonova, M.A.; Popova, N.K. Quantitative RT-PCR assay of 5-HT1A and 5-HT2A serotonin receptor mRNAs using genomic DNA as an external standard. J. Neurosci. Methods 2005, 141, 97-101. [CrossRef]

111. Naumenko, V.S.; Kulikov, A.V. Quantitative assay of 5-HT(1A) serotonin receptor gene expression in the brain. Mol. Biol. 2006, 40, 37-44. [CrossRef]

112. Naumenko, V.S.; Osipova, D.V.; Kostina, E.V.; Kulikov, A.V. Utilization of a two-standard system in real-time PCR for quantification of gene expression in the brain. J. Neurosci. Methods 2008, 170, 197-203. [CrossRef] 